\title{
Manifest Disregard and the Imperfect Procedural Justice of Arbitration
}

\author{
Thomas V. Burch ${ }^{*}$
}

\section{INTRODUCTION}

Since Congress passed the Federal Arbitration Act (FAA) in 1925, an ongoing debate over the importance of efficiency versus accuracy in arbitration has ensued. Much of the debate has focused on the FAA's statutory and nonstatutory grounds for vacatur, particularly on the manifest-disregard doctrine. Critics claim this doctrine implicitly encourages parties to appeal arbitration awards, citing empirical evidence to show that parties rely on it more than any other ground for vacatur. Supporters claim manifest disregard is necessary-even in the limited form that courts usually apply it - to protect parties from arbitrators who fail to follow the law. Either way, the debate itself reveals arbitration as a form of imperfect procedural justice that is based, at least in part, on a utilitarian balancing of procedural costs and the desire for accurate outcomes. ${ }^{1}$

But that's no surprise. Congress passed the FAA with this basic idea in mind. And the United States Supreme Court implicitly recognized the idea when creating the manifest-disregard standard in Wilko v. Swan. ${ }^{2}$ The issue this Article addresses, then, is whether arbitration should focus more on accuracy or on the costs of achieving it. More specifically, it examines whether the manifest-disregard doctrine, in its current form,

Assistant Visiting Professor in Law, Florida State University College of Law. Many thanks to Beth Burch, Brannon Denning, and Stephen Ware for thoughts and comments on previous drafts. All errors, of course, are my own.

1. See JOHN RAWLS, A THEORY OF JUSTICE 85-89 (1971) (explaining imperfect procedural justice as a set of procedures that aims for the correct result while considering "other ends of the law" and trying to achieve "the greatest net balance of satisfaction"); Lawrence B. Solum, Procedural Justice, 78 S. CAL. L. REV. 181, 240 (2004) ("[I]mperfect procedural justice incorporates the notion of an independent criterion for accuracy but adds the notion of 'other ends of the law,' or considerations of cost that may be balanced against accuracy."). I further explore this idea in Part II of this Article.

2. 346 U.S. 427, 436-37 (1953), overruled on other grounds by Rodriguez de Quijas v. Shearson/Am. Express, Inc., 490 U.S. 477 (1989). 
strikes a reasonable balance between these competing interests in the mandatory-arbitration context. ${ }^{3}$

Parts II and III explore the manifest-disregard doctrine, procedural justice in mandatory arbitration, and the relationship between the two. They explain that mandatory arbitration diminishes procedural justice because it creates a control imbalance between the parties and because parties who are subjected to it perceive it as unfair. ${ }^{4}$ These parties dislike being subjected to a dispute-resolution process with limited judicial review. Consider, for example, the narrow manifest-disregard standard that most courts apply. Those courts refuse to review an arbitration award's accuracy unless the moving party shows that the arbitrator consciously ignored known, applicable law. It is virtually impossible for parties to satisfy this standard, which is problematic in mandatory arbitration because parties already have so little control over the process. Parts II and III use this disconnect between manifest disregard and procedural-justice values to support the idea of expanded judicial review under the manifest-disregard standard in mandatory arbitration.

Part IV then explains the limitations of the current manifestdisregard standard and proposes a new standard for courts and other commentators to consider. Specifically, it contends that courts should expand the standard to review awards for legal error in mandatory arbitration - although only for parties who did not draft the arbitration agreement. This will increase decision control by creating a procedural mechanism for correcting arbitrators' mistakes, thereby increasing mandatory arbitration's procedural fairness. Part IV also suggests certain safeguards that should reduce potential abuse of the expanded standard and enhance its procedural fairness, including sanctions and reasoned opinions. This is a case-centric method, and it is an alternative to the

3. "Mandatory arbitration," as used in this Article, refers to employment disputes, consumer disputes, and franchise disputes as those disputes are defined in the Arbitration Fairness Act of 2009. See Arbitration Fairness Act of 2009, H.R. 1020, 111 th Cong. § 3(6) (1st Sess. 2009). It also refers to any arbitration involving (a) a statute that protects civil rights or (b) parties with grossly unequal bargaining power. The former appears in the Arbitration Fairness Act of 2009; the latter appears in the Arbitration Fairness Act of 2007 (although without the "grossly" qualifier). Id. § 4(4); Arbitration Fairness Act of 2007, H.R. 3010, 110th Cong. § 4(4) (1st Sess. 2007).

4. To be clear, I am not attempting to compare arbitration's procedural justice to the procedural justice of trials or any other dispute-resolution procedure. Two of the points I make in this Article are (a) that courts place too much emphasis on the limited-review principle-namely, efficiency - in mandatory arbitration, which has led to calls for abolishing mandatory arbitration and (b) that instead of abolishing mandatory arbitration, we should place more emphasis on accuracy, and less on efficiency, by expanding the manifest-disregard standard in the mandatory-arbitration context. So, instead of comparing the procedural justice of arbitration to the procedural justice of trials, I am simply saying that if we are going to allow mandatory arbitration to exist, we should enhance its procedural fairness. 
incoherent and inequitable manifest-disregard standard that exists today. More broadly, it is an alternative method of reforming mandatory arbitration — an idea that seems to be gaining popular appeal. ${ }^{5}$

\section{ARBitration AND IMPERfECt PRocedural Justice}

The Federal Arbitration Act's legislative history shows that Congress wanted to create an efficient dispute-resolution system that would respect parties' rights to an accurate award. ${ }^{6}$ But that same history does not show where, exactly, Congress wanted to draw the line between these competing interests. ${ }^{7}$ So courts have been tasked with crafting an arbitration system that fleshes out Congress's amorphous intent, and the result has been a patchwork of decisions that elevates efficiency over accuracy and fairness. ${ }^{8}$

5. See Consumer Financial Protection Agency Act of 2009, H.R. 3126, 111th Cong. § 125 (1st Sess. 2009) (giving the proposed agency the power to prohibit or impose limitations of mandatory arbitration by rule if the agency decides such a rule would benefit the public interest); H.R. 1020, $\S 4$ (4) (attempting to eliminate predispute arbitration agreements for consumer, employment, and franchise disputes and for disputes arising under statutes that protect civil rights); H.R. 3010, § 4(4) (same); see also Jean R. Sternlight, Creeping Mandatory Arbitration: Is It Just?, 57 STAN. L. REV. 1631, 1674-75 (2005) (calling for a new approach to mandatory arbitration because it is "unjust"); Press Release, Nat'l Arbitration Forum, National Arbitration Forum to Cease Administering All Consumer Arbitrations in Response to Mounting Legal and Legislative Challenges (July 19, 2009) (on file with author), available at http://www.adrforum.com/newsroom.aspx?itemID=1528.

6. See H.R. REP. NO. 68-96, at 2 (1924) ("The [enforcement] procedure is very simple, following the lines of ordinary motion procedure, reducing technicality, delay, and expense to a minimum and at the same time safeguarding the rights of the parties.").

7. While the FAA includes several grounds for overturning arbitration awards, those grounds are narrow. See 9 U.S.C. $\S 10$ (2006) (stating that courts may overturn arbitration awards where there is evidence of an award procured by fraud, partiality or corruption of the arbitrators, misconduct by the arbitrators in refusing to postpone a hearing or failing to hear evidence, or arbitrators exceeding their powers). So one could assume that in choosing between efficiency and accuracy, Congress chose efficiency. Although the assumption probably would be correct, the reasoning would be thin.

8. For example, starting in the 1980 s the Supreme Court pushed a "national policy favoring arbitration," encouraging courts to enforce arbitration agreements and subjecting a wider range of disputes to arbitration. See Southland Corp. v. Keating, 465 U.S. 1, 10 (1984) ("In enacting $§ 2$ of the federal Act, Congress declared a national policy favoring arbitration and withdrew the power of the states to require a judicial forum for the resolution of claims which the contracting parties agreed to resolve by arbitration."); see also Circuit City Stores, Inc. v. Adams, 532 U.S. 105, 119 (2001) (extending the reach of the FAA over statutory claims); Gilmer v. Interstate/Johnson Lane Corp., 500 U.S. 20, 28-29 (1991) (finding that ADEA claims may be resolved through arbitration); Rodriguez de Quijas v. Shearson/Am. Express, Inc., 490 U.S. 477, 483-84 (1989) (finding that claims under the Securities Act of 1933 may be resolved through arbitration); Mitsubishi Motors Corp. v. Soler Chrysler-Plymouth, Inc., 473 U.S. 614, 627 (1985) (finding that statutory claims may be resolved through arbitration). Lower courts have relied on this national policy as a rationale for giving greater deference to arbitrators' decisions, thus reducing the likelihood of those decisions being overturned on appeal. See, e.g., Ferro Corp. v. Garrison Indus., Inc., 142 F.3d 926, 930 (6th 
While some commentators claim that this emphasis on efficiency has caused arbitration to become "lawless," most believe that courts are getting it right - that Congress intended efficiency to be the compelling interest. $^{10}$ Ultimately I agree. But I also believe the emphasis on efficiency versus accuracy has shifted over time, with Congress and the public placing increasing emphasis on accuracy in recent years. ${ }^{11}$

This shift is a reaction against the Supreme Court's "national policy favoring arbitration" and the corresponding growth of mandatory arbitration over the last two decades. ${ }^{12}$ Consumers, employees, patients,

Cir. 1998); Willoughby Roofing \& Supply Co. v. Kajima Int'l, Inc., 598 F. Supp. 353, 356 (N.D. Ala. 1984).

9. See Charles L. Knapp, Taking Contracts Private: The Quiet Revolution in Contract Law, 71 FORDHAM L. REV. 761, 783 (2002) ("Arbitrators of course may choose to follow the law-nothing requires them not to- but if they do, it's not because they have any obligation to do so, and it's not something that a litigant or her attorney can count on going in."); Heinrich Kronstein, Business Arbitration-Instrument of Private Government, 54 YALE L.J. 36, 66 (1944) (criticizing the "lawlessness" of organized arbitration). But see Christopher R. Drahozal, Is Arbitration Lawless?, 40 LOY. L.A. L. REV. 187, 190 (2006) (“[P]erhaps surprisingly, the available empirical evidence to date provides at best weak support for the view that arbitration is 'lawless."'); William W. Park, The Specificity of International Arbitration: The Case for FAA Reform, 36 VAND. J. TRANSNAT'L L. 1241, $1290 \mathrm{n} .217$ (2003) ("The assertion that arbitrators are allowed to be lawless is at odds with the existence of 'manifest disregard of the law' as a standard for judicial review, and inconsistent with the provisions of many arbitration rules."). The same debate exists over arbitration under state laws that are based on the Uniform Arbitration Act and the Revised Uniform Arbitration Act. But under those Acts, fairness may be gaining ground on efficiency as the preferred policy. See generally, e.g., Michael H. LeRoy, Misguided Fairness? Regulating Arbitration by Statute: Empirical Evidence of Declining Award Finality, 83 NOTRE DAME L. ReV. 551 (2008) (expressing concerns that state arbitration statutes based on the RUAA elevate fairness principles over finality of awards).

10. See, e.g., Stephen L. Hayford, Reining in the "Manifest Disregard" of the Law Standard: The Key to Restoring Order to the Law of Vacatur, 1998 J. DiSP. RESOL. 117, 118 (stating that finality is the "essential feature" of arbitration); LeRoy, supra note 9, at 581 ("The FAA was passed to make arbitration a quick, efficient, low-cost alternative to courts."); Michael H. LeRoy \& Peter Feuille, Happily Never After: When Final and Binding Arbitration Has No Fairy Tale Ending, 13 HARV. NEGOT. L. REV. 167, 205 (2008) ("When arbitration becomes a preliminary step in a prolonged dispute resolution process, it has failed.").

11. See, e.g., Arbitration Fairness Act of 2009, H.R. 1020, 111th Cong. § 2(5) (1st Sess. 2009) ("Mandatory arbitration undermines the development of public law for civil rights and consumer rights, because there is no meaningful judicial review of arbitrators' decisions."); see also U.S. DeP'T OF THE TREasury, FinANCial Regulatory ReForm, A NeW Foundation: Rebuilding FinANCIAL SUPERVISION AND REgULATION 62 (2009) ("Many consumers do not know ... that a private party dependent on large firms for their business will decide the case without offering the right to appeal or a public review of decisions."), available at http://www.financialstability.gov/ docs/regs/FinalReport_web.pdf; Calvin William Sharpe, Integrity Review of Statutory Arbitration Awards, 54 HASTINGS L.J. 311 (2003) (calling for greater review of awards in arbitrations involving statutory claims).

12. See Southland, 465 U.S. at 10 ("In enacting $\S 2$ of the federal Act, Congress declared a national policy favoring arbitration and withdrew the power of the states to require a judicial forum for the resolution of claims which the contracting parties agreed to resolve by arbitration."); see also Sternlight, supra note 5, at 1632-33 (explaining how the "national policy" led to an increase in mandatory arbitration). 
franchisees, and public interest groups are demanding more procedural fairness in arbitration, usually by calling for greater judicial review of legally inaccurate awards. They believe that being "forced" into a dispute resolution procedure with few options for error correction is unfair, which explains the increased tension over arbitration's efficiency policy, including questions over whether it justifies limiting certain parties' procedural right to challenge legally inaccurate awards. ${ }^{13}$

This ongoing conflict between efficiency and accuracy shows that arbitration is a form of imperfect procedural justice, one that has independent criteria for accuracy while also considering "other ends of the law." 14 The following Section briefly examines procedural justice in arbitration, with a particular focus on the role that manifest disregard plays in balancing efficiency and accuracy. It starts with a brief background on the concept of procedural justice.

\section{A. A Primer on Procedural Justice}

Procedural justice has been considered in two different contexts: political philosophy and social psychology. While this Article principally addresses the latter, it initially uses the former to explain arbitration's particular brand of procedural justice, drawing from John Rawls to illustrate what arbitration is and what it is not.

In A Theory of Justice, Rawls set out three basic forms of procedural justice: perfect, imperfect, and pure. ${ }^{15}$ He illustrated perfect procedural justice by describing a fair process for equally dividing a cake (making the assumption that an equal division is a fair division). ${ }^{16}$ The person slicing the cake takes the last piece, thereby ensuring equal shares. ${ }^{17}$ This illustrates the two main features of perfect procedural justice. ${ }^{18}$ First, it has an independent criterion for determining what constitutes the correct result — equal slices. ${ }^{19}$ Second, it has a procedure for ensuring the

13. As the Court expanded the scope of arbitrable claims and encouraged lower courts to defer to arbitrators' awards, efficiency was one of its main justifications, but it still expressed support for accurate awards. See, e.g., Mitsubishi Motors Corp., 473 U.S. at 628 ("By agreeing to arbitrate a statutory claim, a party does not forgo the substantive rights afforded by the statute; it only submits to their resolution in an arbitral, rather than a judicial, forum.").

14. See RAWLS, supra note 1 , at 85 .

15. Id. at $83-90$.

16. Id. at 85 .

17. $I d$.

18. Id.

19. This independent criterion is defined separately from the procedure used to obtain the fair division. Id. 
desired outcome-slicer picks last. ${ }^{20}$ As Rawls conceded, perfect procedural justice is rare in "cases of much practical interest.",1

Unlike perfect procedural justice, pure procedural justice has no independent criterion for determining the correct result. ${ }^{22}$ Instead, it has fair procedures that, if followed, lead to a fair outcome. ${ }^{23}$ Take, for instance, Rawls's gambling example. If a group of people undertakes a series of fair bets, then the distribution of money after the last bet is fair whatever it is-assuming, among other things, that no one cheats. ${ }^{24}$ This is so because the betting procedures are fair and because the group members freely choose to place the bets under conditions that are fair. ${ }^{25}$ But fair procedures translate into fair results only when carried out. ${ }^{26}$ So, because there is no independent criterion for determining fair results, achieving pure procedural justice depends on implementing the fair procedures. $^{27}$

Finally, Rawls illustrated imperfect procedural justice by describing a criminal trial. ${ }^{28}$ The desired outcome is that the defendant is found guilty only if she committed the act she has been accused of committing. ${ }^{29}$ But it is impossible to design procedures that consistently achieve this result. ${ }^{30}$ The trick, then, is to design procedures that promote accuracy while also considering the law's other ends, like costs. ${ }^{31}$ Thus, the characteristic feature of imperfect procedural justice is an independent criterion for a desired outcome - conviction only if guilty - but no feasible procedure for consistently obtaining that outcome because "other ends of the law" must be considered. ${ }^{32}$

Arbitration fits Rawls's concept of imperfect procedural justice. Although it has an independent criterion for determining the correct result - perfect accuracy for awards - it has no feasible procedure for achieving that result because it takes costs into account. In other words,

20. Id.

21. Id.

22. Id. at 86 .

23. $I d$.

24. Id.

25. $I d$.

26. $I d$.

27. Id. at $86-87$.

28. Id. at 85 .

29. Id.

30. Id.; see also Solum, supra note 1, at 185 ("Procedural perfection is unattainable. No conceivable system of procedure can guarantee perfect accuracy.").

31. It requires, in other words, balancing. RAWLS, supra note 1, at 85 .

32. Id. 
because arbitration is designed to be an efficient process, it cannot guarantee the awards' accuracy. This presents a challenge when courts are asked to confirm or vacate arbitrators' decisions. Judges dislike approving inaccurate awards, especially in cases where parties have unequal bargaining power. Yet, judges also recognize arbitration's limited-review principle. So they are forced to balance their desire for accuracy against arbitration's efficiency policy. Efficiency typically wins at the expense of accurate outcomes. ${ }^{33}$

To Rawls, the idea behind procedural justice is designing a process that leads to just outcomes. ${ }^{34}$ But Rawls wrote to a very different audience; he did not explore this idea in the context of resolving legal disputes. John Thibaut and Laurens Walker were two of the first to do so. ${ }^{35}$ They studied parties' psychological responses to variations in dispute-resolution procedures, and, in a series of studies and articles, they advanced three arguments regarding parties' procedural preferences: (1) that perceptions of procedural fairness influence procedural preferences, (2) that distribution of control within procedures determines preferences, and (3) that parties prefer procedures that allow them to control the information that is used to resolve the dispute. ${ }^{36}$ Their arguments show the importance of control and of parties' subjective views on procedural fairness - two of procedural justice's main features. $^{37}$

As to control, Thibaut and Walker identified two types. The first, process control, refers to control over the development and presentation

33. This is exhibited by the narrow manifest-disregard standard that most courts apply. See cases cited supra note 8. Those courts refuse to review arbitration awards for legal error unless the moving party shows that the arbitrator consciously ignored known, applicable law. See cases cited supra note 8. Legal mistakes usually do not suffice under this standard. See Norman S. Poser, Judicial Review of Arbitration Awards: Manifest Disregard of the Law, 64 BrooK. L. REV. 471, 471-72 (1998) (explaining the Second Circuit's manifest-disregard standard).

34. RAWLS, supra note 1 , at 85 .

35. See John W. Thibaut \& Laurens Walker, Procedural Justice: A Psychological ANALYSIS vii (1975) [hereinafter ThIBAut \& WALKer, Procedural Justice]; Pauline Houlden et al., Preference for Modes of Dispute Resolution as a Function of Process and Decision Control, 14 J. EXPERIMENTAL SOC. PSYCHOL. 13 (1978); John Thibaut \& Laurens Walker, A Theory of Procedure, 66 CAL. L. REV. 541, 541 (1978) [hereinafter Thibaut \& Walker, A Theory of Procedure]; John Thibaut et al., Procedural Justice as Fairness, 26 StAn. L. Rev. 1271, 1273 (1974); Laurens Walker et al., The Relation Between Procedural and Distributive Justice, 65 VA. L. REV. 1401, 1401 (1979).

36. Debra L. Shapiro \& Jeanne M. Brett, Comparing Three Processes Underlying Judgments of Procedural Justice: A Field Study of Mediation and Arbitration, 65 J. PERSONALITY \& Soc. PSYCHOL. 1167, 1167 (1993) (summarizing Thibaut and Walker's work).

37. See Donna Shestowsky \& Jeanne Brett, Disputants' Perceptions of Dispute Resolution Procedures: An Ex Ante and Ex Post Longitudinal Empirical Study, 41 ConN. L. REV. 63, 71 (2008) (discussing the importance of these features in procedural justice). 
of information used to resolve a dispute. ${ }^{38}$ The second, decision control, focuses on a party's ability to shape a dispute's outcome. ${ }^{39}$ In arbitration, parties typically have high process control and low decision control. ${ }^{40}$ But that varies based on the disparity in parties' bargaining power. The party with the greatest bargaining power dictates control distribution. That is, the party with greater bargaining power controls the arbitration agreement, so it also controls how disputes under the agreement are resolved. Too much control diminishes procedural justice for the other party to the dispute because the other party has little influence over the process or outcome. ${ }^{41}$

As to parties' subjective views on procedural fairness, Thibaut and Walker's work supports three important ideas. First, parties' satisfaction with procedural fairness strongly correlates with parties' outcome satisfaction. ${ }^{42}$ In other words, parties are more likely to be satisfied with an outcome if they believe the procedure used to obtain it was fair. ${ }^{43}$ Employing fair procedures also enhances the chances of parties accepting and complying with the outcome, thus reducing the likelihood of post-dispute conflict and enforcement costs. ${ }^{44}$ Second, because the parties "own" their dispute and want control over how their dispute is resolved, their preferences should guide its resolution. ${ }^{45}$ This simply

38. For example, giving a party the right to plan how it will present evidence enhances that party's process control. Thibaut \& Walker, A Theory of Procedure, supra note 35, at 546.

39. Id. ("Decision control is measured by the degree to which any one of the participants may unilaterally determine the outcome of the dispute.").

40. Robert Folger, Mediation, Arbitration, and the Psychology of Procedural Justice, in 1 RESEARCH ON NEGOTIATION IN ORGANIZATIONS 57, 58 (1986).

41. See Sternlight, supra note 5, at 1635 ("[I]t is highly problematic to permit the most powerful actors in a society to craft a dispute resolution system that is best for them but not necessarily their opponents or the public at large.").

42. See E. Allan Lind \& Tom R. Tyler, The Social Psychology of Procedural Justice 66 (1988) ("A number of studies have found evidence of either direct or indirect enhancement of evaluations of legal outcomes when procedures are viewed as fair.”); THIBAUT \& WALKER, PROCEDURAL JUSTICE, supra note 35, at 94 (same).

43. See Thibaut \& Walker, Procedural Justice, supra note 35, at 94; see also Walker et al., supra note 35, at 1415-16 (stating that perceptions of procedural justice enhance perceptions of outcomes for participants in the decision-making process).

44. See Shestowsky \& Brett, supra note 37, at 72-73 (citing studies); Tom R. Tyler, Procedural Justice and the Courts, 44 CT. REV. 26, 26 (2007) [hereinafter Tyler, Procedural Justice and the Courts]; Tom R. Tyler, Procedural Justice, Legitimacy, and the Effective Rule of Law, 30 CRIME \& Just. 283, 284 (2003); Tom R. Tyler, Trust and Law Abidingness: A Proactive Model of Social Regulation, 81 B.U. L. REV. 361, 367 (2001); Walker et al., supra note 35, at 1416.

45. Shestowsky \& Brett, supra note 37, at 71; see also Tom R. Tyler, Citizen Discontent with Legal Procedures: A Social Science Perspective on Civil Procedure Reform, 45 AM. J. CoMP. L. 871, 874-75 (1997) (stating that justice "develops from the concerns, needs, and values of the people who bring their problems to the legal system"). 
means that legal decisions, to the extent possible, should follow a procedure that the parties agree is just. ${ }^{46}$ Finally, parties' subjective views are important because "they can be used to advance the goals of democratic governance." ${ }^{47}$ That is, legal procedures should be consistent with the public's values and desires over time. ${ }^{48}$ Given this need for consistency, we should translate parties' subjective views on procedures into policies effectuating those views. ${ }^{49}$

But procedural justice doesn't focus solely on parties' subjective beliefs; it has an objective component as well. So it can be discussed in terms of subjective or objective standards. ${ }^{50}$ In other words, procedural justice can focus on what makes some procedures seem fairer than others, or it can focus on whether certain procedures lead to more accurate or just outcomes. ${ }^{51}$ While this is consistent with the two main goals of the judicial system - to correctly apply the law to given sets of facts and to apply the law in such a way that parties willingly comply with courts' decisions ${ }^{52}$ - these goals often conflict. The question, then, is whether procedures for applying the law can confer legitimacy on an incorrect decision.

Although some tension between outcome-based and process-based models of procedural justice exists, ${ }^{53}$ research has shown that parties may independently assess outcomes and the procedures that lead to them. ${ }^{54}$ In other words, the outcome need not be favorable for the parties to perceive the procedure as fair. ${ }^{55}$ Parties assess the procedure itself, specifically evaluating the amount of control it offers. ${ }^{56}$ And the

46. Tyler, supra note 45 , at 874 ("People should be able to willingly embrace the solutions reached in legal proceedings.").

47. Shestowsky \& Brett, supra note 37, at 71; see also Richard C. Reuben, Democracy and Dispute Resolution: The Problem of Arbitration, 67 LAW \& CONTEMP. PROBS. 279, 282 (2004) (“As a dispute-resolution process, arbitration is generally undemocratic, but it acquires democratic legitimacy when parties actually agree to arbitrate their disputes because it furthers the unifying democratic value of personal autonomy. When involuntary, however, arbitration only frustrates the larger goals of democratic governance.").

48. See Tyler, supra note 45, at 871-72; Shestowsky \& Brett, supra note 37, at 71.

49. Shestowksy \& Brett, supra note 37 , at 71-72.

50. LIND \& TYLER, supra note 42, at 3 ("The justice of social processes, procedures, and outcomes can be discussed with reference to either subjective or objective standards.").

51. Id.

52. Tyler, Procedural Justice and the Courts, supra note 44, at 26.

53. LIND \& TYLER, supra note 42, at 1-2 ("There is a tension between outcome-based and process-based models of the person that manifests itself repeatedly in procedural justice research.").

54. Shestowsky \& Brett, supra note 37, at 68-69 (citing studies); see also LIND \& TYLER, supra note 42 .

55. Shestowsky \& Brett, supra note 37, at 68-69 (citing studies).

56. Id. at 69 (citing studies); Shapiro \& Brett, supra note 36, at 1167. 
outcome alone does not always reflect parties' overall satisfaction with the dispute resolution process. Rather, process satisfaction is a function of both the outcome and the fairness of the procedures followed. ${ }^{57}$ Thus, parties might consider themselves bound to an incorrect decision "if it results from a procedure that affords [the parties] a meaningful opportunity to participate in a process that strikes a reasonable balance between the goal of accurate outcomes and the inevitable costs imposed by any system of dispute resolution." ${ }^{, 58}$ And that is the issue this Article addresses in the mandatory-arbitration context. Does its system of procedures, specifically focusing on the doctrine of manifest disregard, strike that reasonable balance? The answer is no, and the next Section explains why.

\section{B. Procedural Justice, Mandatory Arbitration, and Decision Control}

When Congress passed the Federal Arbitration Act, arbitration typically involved business-to-business disputes. ${ }^{59}$ But the Supreme Court subsequently announced a "national policy favoring arbitration" that encouraged courts to enforce arbitration agreements, ${ }^{60}$ which, in turn, spawned an increase in mandatory arbitration. ${ }^{61}$ Businesses began

57. See Deborah R. Hensler, Judging Arbitration: The Findings of Procedural Justice Research, in AM. ARBITRATION Ass'N, HANDBOOK ON COMMERCIAl ARBITRATION 41, 43 (Thomas E. Carbonneau et al. eds., 2006) (stating that procedural justice scholars have "consistently found that the degree of satisfaction with the legal process is a function of an individual's perception of the fairness of both the process and the outcome").

58. Solum, supra note 1, at 190.

59. See Sternlight, supra note 5, at 1636 (noting that mandatory arbitration has emerged over the last two decades); Stephen J. Ware, Default Rules from Mandatory Rules: Privatizing Law Through Arbitration, 83 MiNN. L. REV. 703, 712-13 (1999) ("Only recently, however, has arbitration become significant outside the commercial and labor areas. This expansion was largely driven by the Supreme Court. The Court's arbitration decisions over the last twenty-five years greatly expanded the scope of arbitrable claims."); Maureen A. Weston, Reexamining Arbitral Immunity in an Age of Mandatory and Professional Arbitration, 88 MINN. L. REV. 449, 459 (2004) ("The use of arbitration has changed significantly since the FAA's inception in 1925, from the traditional model involving voluntary arbitration between parties of relatively equal bargaining power, to a system where arbitration has become a profession and a commercialized industry that is imposed upon consumers and employees."). Sternlight also notes that Congress probably did not intend arbitration to be used by businesses against consumers. Sternlight, supra note 5, at 1636 ("Indeed, to the limited extent that the possibility of such arbitration was considered by Congress in 1925, when it passed the FAA, those few who spoke on the issue made clear that they did not view such a use of arbitration as appropriate.").

60. Southland Corp. v. Keating, 465 U.S. 1,10 (1984).

61. See Sternlight, supra note 5, at 1632 (explaining how the "national policy" led to an increase in mandatory arbitration). Section 2 of the FAA makes arbitration provisions in contracts "evidencing a transaction involving commerce" enforceable. 9 U.S.C. § 2 (2006). The Supreme Court's "national policy favoring arbitration" coincided with its expansion of the Commerce Clause 
requiring consumers, employees, franchisees, patients, and others to arbitrate disputes and limited those parties' basic procedural rights through their arbitration agreements. ${ }^{62}$ And they implemented these agreements knowing how difficult it is to overturn an arbitration award on appeal. ${ }^{63}$ In other words, they implemented favorable procedural changes under their arbitration agreements knowing that their changes would be insulated from judicial review. ${ }^{64}$

Enforcing these mandatory-arbitration agreements negatively affects perceptions of procedural justice. It seems unfair that a party can design a process that limits basic procedural rights and impose it on another, particularly if that process limits judicial review. ${ }^{65}$ Parties understandably question procedural fairness under such circumstances. ${ }^{66}$ And if legal decisions should be reached following a procedure that the parties agree is just, then each party's procedural preferences should be taken into account. ${ }^{67}$ Thibaut and Walker showed the importance of these subjective views on procedural fairness. ${ }^{68}$ And other studies have shown the importance that parties in arbitration place on fairness overall.

to cover activities "affecting" interstate commerce, which could help explain the Court's expansion of disputes that can be subject to arbitration over the last twenty to twenty-five years. See Southland, 465 U.S. at 10-11 (discussing the national policy favoring arbitration in conjunction with the Commerce Clause); see also Allied-Bruce Terminix Cos. v. Dobson, 513 U.S. 265, 273-74 (1995) (same).

62. For example, some mandatory arbitration agreements contain provisions that severely limit discovery, eliminate the right to class actions, forbid cross-examination of witnesses, and impose biased arbitrators. See Sternlight, supra note 5, at 1644-45; Elizabeth G. Thornburg, Contracting with Tortfeasors: Mandatory Arbitration Clauses and Personal Injury Claims, 67 LAW \& CONTEMP. PROBS. 253, 262-63 (2004) (stating that parties who draft the arbitration agreement can create procedural rules that "can eliminate or severely limit basic procedural rights, including affordable access to the dispute resolution forum, discovery, class action, live hearings and cross-examination of witnesses, the use of unbiased decisionmakers, process transparency, and reasoned, written opinions.").

63. See Sternlight, supra note 5, at 1637-38, 1645-46.

64. Thornburg, supra note 62, at 266 ("A further problem is that the FAA largely insulates procedural changes and limitations on remedies from judicial review."); see also Sternlight, supra note 5, at 1644-46 (discussing the difficulty of appealing an arbitration award).

65. See Sternlight, supra note 5, at 1671 ("Even if the process which is being forced is itself 'fair,' the forcing of that process on one side by the other raises the concern, from a procedural justice standpoint, that the process is tainted.").

66. See Stephan Landsman, ADR and the Cost of Compulsion, 57 STAN. L. REV. 1593, 1624-25 (2005) ("The results of compelling the use of ADR are predictable. No matter how benign its goals and its rhetoric, compelled ADR often thwarts disputant independence and fails to provide those sorts of procedures capable of assuaging concerns about fairness.").

67. See Tyler, supra note 45 , at 874 (stating that the parties to a dispute should reach a consensus about what is just); see also Linda Musante et al., The Effects of Control on Perceived Fairness of Procedures and Outcomes, 19 J. EXPERIMENTAL SoC. PSYCHOL. 223, 225 (1983) (finding that allowing parties to participate in rule selection enhances procedural justice).

68. See Shestowsky \& Brett, supra note 37, at 71 (describing Thibaut and Walker's work). 
For example, Richard Naimark and Stephanie Keer authored a recent study that asked arbitration participants to rank eight factors in order of importance: fair and just result, cost, monetary award, finality of decision, speed, arbitrator expertise, privacy, and future relations. ${ }^{69}$ "Fair and just result" ranked first by a substantial margin, with eighty-one percent of participants giving it the highest possible ranking. " "Cost," "speed," "arbitrator expertise," and "monetary award" were part of a four-way statistical tie for second. ${ }^{71}$ And "finality" came in just behind that group. ${ }^{72}$ Thus, "fair and just result" outranked the other, more traditional arbitration characteristics.

The authors also found that "fair and just result" includes elements of substantive and procedural justice. ${ }^{73}$ So the parties care about getting the right result in the right way. ${ }^{74}$ Mandatory arbitration inhibits procedural justice in this regard because it creates a control imbalance between the parties. $^{75}$ The party with less bargaining power has little to no say in how the arbitration will proceed, and it has little control over the ultimate award. This is problematic given that one of the fundamental characteristics of procedural justice is control. ${ }^{76}$ Parties like control over the outcome-decision control - and control over the procedures that lead to the outcome-process control. ${ }^{77}$ In fact, several studies

69. See Richard W. Naimark \& Stephanie E. Keer, International Private Commercial Arbitration: Expectations and Perceptions of Attorneys and Business People, 30 INT'L Bus. LAW. 203, 203-04 (2002) (describing the study).

70. Id. at 204 ("This means that a fair and just result was nearly twice as important as the next closest rankings."). "Fair and just result" ranked first among both claimants and respondents. Id. Also, participants ranked all of the characteristics both before and after their arbitrations. Id. The percentage of participants who ranked "fair and just result" as the most important characteristic actually increased in the surveys given after the arbitration proceedings. Id.

71. Id. at 206. There was a small difference between the rankings for "cost" and "monetary award." Id. at 204. Forty-six percent of the participants gave "cost" the highest possible ranking, while forty-three percent gave "monetary award" the highest possible ranking. Id.

72. Id. at 207. While this study was performed on international commercial arbitration, its results are nevertheless instructive for mandatory arbitrations between commercial parties and individuals.

73. Id. at 205 .

74. Id. ("Simply winning does not explain the ranking tendency. Getting the result in the "right way', procedural justice also speaks strongly to the participants in these arbitrations.”).

75. Edward Brunet et al., Arbitration law in America: A Critical Assessment 6-7 (2006) ("Bilateral consent to arbitrate is essential to autonomy and to freedom. If only one party wants arbitration, the other party loses party control.").

76. See Thibaut \& Walker, A Theory of Procedure, supra note 35, at 546 ("The distribution of control among the procedural group participants is the most significant factor in characterizing a procedural system."); see also Folger, supra note 40, at 57-58 (same); Shapiro \& Brett, supra note 36, at 1167 (discussing the importance of control in procedural justice).

77. See Thibaut \& Walker, A Theory of Procedure, supra note 35, at 546 ("'Control' involves at least two elements: control over the decision and control over the process."); see also Folger, supra 
performed in the context of arbitration have shown that parties prefer direct control over the outcome in the form of appeal mechanisms. ${ }^{78}$ Giving such control to the parties enhances procedural justice. ${ }^{79}$ This is true not only because it represents an opportunity to exercise control, but also because it indicates that the system safeguards against error and bias. $^{80}$

For example, Donna Shestowsky published a study in 2004 that examined preferences for decision control, process control, and control over substantive rules in small-claim disputes between individuals. ${ }^{81}$ Taking into account social status (equal versus lower) and role (plaintiff versus defendant), Shestowsky looked into the type of dispute-resolution features that parties prefer and whether parties' preferences varied depending on the type of dispute. ${ }^{82}$ Through three separate experiments, she ultimately found that parties prefer having veto power over a third party's decision to having a third party make a binding decision. ${ }^{83}$

It is therefore worth considering how much control parties in mandatory arbitration should have over rejecting an arbitrator's award. More specifically, given the conflict in arbitration between efficiency and accuracy, it is worth considering the control that parties have over rejecting an arbitrator's award for legal error and whether that control is sufficient from a procedural justice standpoint. The answer, in short, is that parties have multiple grounds for appealing an award, ${ }^{84}$ but only one of the available grounds, manifest disregard, allows courts to examine the accuracy of the award while taking into consideration "other ends of

note 40 , at 58 (describing decision control and process control).

78. Folger, supra note 40, at 63-69 (summarizing studies); see also Elizabeth Chamblee Burch, Nonjurisdictionality or Inequity, 102 Nw. U. L. REV. COLLOQUY 64, 67 (2007) ("For litigants, appellate process is inherently part of procedural justice.").

79. Folger, supra note 40, at 68.

80. Id. at 67 .

81. Donna Shestowsky, Procedural Preferences in Alternative Dispute Resolution: A Closer, Modern Look at an Old Idea, 10 PSYCHOL. PUB. POL'Y \& L. 211 (2004).

82. Id. at $211-12$.

83. Id. at $233-35,240-41$. Shestowsky stated that, because her study involved small-claims disputes between individuals, "the findings reported here may not apply to higher stake civil disputes, disputes with corporations, or disputes involving issues relevant to criminal law." Id. at 214. But the results of her study do seem to translate to disputes between individuals and commercial parties, anecdotally at least. Consider, for example, how much of the recent push against mandatory arbitration has been based on the lack of judicial review for legally inaccurate awards. See sources cited supra note 11.

84. See 9 U.S.C. $\S 10$ (2006) (listing the circumstances under which a court may vacate an award); Wilko v. Swan, 346 U.S. 427, 436-37 (1953) (discussing judicial review of arbitration awards), overruled on other grounds by Rodriguez de Quijas v. Shearson/Am. Express, Inc., 490 U.S. 477 (1989). 
the law," like costs. ${ }^{85}$ Manifest disregard forces courts to balance the importance of efficiency and accuracy in arbitration, thus showing arbitration as a form of imperfect procedural justice. ${ }^{86}$ The question, then, is whether manifest disregard, in its current form, strikes a reasonable balance between these competing interests.

\section{MANIFEST DISREGARD IN ITS CURRENT FORM}

When reviewing arbitration awards, courts struggle to balance efficiency and accuracy, particularly when it comes to applying the manifest-disregard doctrine. ${ }^{87}$ In part, this is because the doctrine remains largely undefined; courts can mold it to fit the needs of any particular case. ${ }^{88}$ But whatever the cause, the result has been a myriad of inconsistent interpretations of the doctrine. Some are based on the idea that an arbitrator cannot consciously ignore known, applicable law. Some focus less on the arbitrator's mental state and more on the inequity of allowing an egregious legal error to stand regardless of whether the arbitrator intended the error. Because of these inconsistencies, it is a flawed doctrine, and it will continue to be flawed until courts adopt a more consistent way to apply it.

85. See RAWLS, supra note 1, at 85 (explaining the balance of accuracy against other ends of the law).

86. See Poser, supra note 33, at 505 ("[T]he manifest disregard ground is an attempt to balance 'the public interest in having arbitrators stay within the applicable law versus the public policy in favor of speedy and economical function of the arbitration process." (quoting Marta B. Varela, Arbitration and the Doctrine of Manifest Disregard, 49 DisP. RESOL. J. 64, 71 (1994))).

87. Some interpret the manifest-disregard standard more broadly than others, thus subjecting awards to more detailed review. Compare Prudential-Bache Sec., Inc. v. Tanner, 72 F.3d 234, 240 (1st Cir. 1995) ("In order to demonstrate that the arbitrator both recognized and ignored the applicable law, 'there must be some showing in the record, other than the result obtained, that the arbitrators knew the law and expressly disregarded it."' (citations omitted)), and Health Servs. Mgmt. Corp. v. Hughes, 975 F.2d 1253, 1267 (7th Cir. 1992) (“[T]o vacate an arbitration award for manifest disregard of the law, there must be something beyond and different from mere error in law or failure on the part of the arbitrators to understand or apply the law ....'), with Willemijn Houdstermaatschappij, BV v. Standard Microsystems Corp., 103 F.3d 9, 13 (2d Cir. 1997) ("[A] court may infer that the arbitrators manifestly disregarded the law if it finds that the error made by the arbitrators is so obvious that it would be instantly perceived by the average person qualified to serve as an arbitrator.”), Cole v. Burns Int'l Sec. Servs., 105 F.3d 1465, 1487 (D.C. Cir. 1997) (stating that the Supreme Court's "assumptions regarding the arbitration of statutory claims are valid only if judicial review under the 'manifest disregard of the law' standard is sufficiently rigorous to ensure that arbitrators have properly interpreted and applied statutory law."), and Advest, Inc. v. McCarthy, 914 F.2d 6, 10 (1st Cir. 1990) ("In certain circumstances, the governing law may have such widespread familiarity, pristine clarity, and irrefutable applicability that a court could assume the arbitrators knew the rule and, notwithstanding, swept it under the rug.").

88. See Hayford, supra note 10, at 122-32 (explaining how courts have given manifest disregard different, and conflicting, definitions over time). 
But before explaining how the current doctrinal applications should be changed, this Article first explains, in a little more detail, why. To do so requires a brief history of the doctrine, a description of its different applications, and an explanation of how those applications reflect courts' inability to choose between efficiency and accuracy as the more important arbitration policy.

\section{A. The Foundation of, and Methods of Applying, the Doctrine}

The Supreme Court created the manifest-disregard-of-the-law doctrine in $1953 .{ }^{89}$ And it did so as dicta in a case that it subsequently overturned (on other grounds). ${ }^{90}$ In fact, all the Court said was, "In unrestricted submissions, ... the interpretations of the law by the arbitrators in contrast to manifest disregard are not subject, in the federal courts, to judicial review for error in interpretation." 91 That was the extent of the Court's discussion. It gave no further details on what manifest disregard of the law meant, and it gave no indication that it even intended manifest disregard to constitute a new ground for vacating arbitration awards under the FAA. ${ }^{92}$ So the doctrine has no concrete foundation, which is the most frequent criticism against it. ${ }^{93}$

But that has not prevented lower courts - and the Supreme Court itself-from continuing to recognize the doctrine as a ground for vacating arbitration awards. In fact, every federal circuit court of appeals has adopted it (although the Fifth and Eleventh Circuits have since renounced it), ${ }^{94}$ many state courts have adopted it, ${ }^{95}$ and parties seeking

89. See Wilko, 346 U.S. at 436-37 (first mentioning manifest disregard).

90. Id.

91. Id.

92. Hall St. Assocs. v. Mattel, Inc., 552 U.S. 576, 585 (2008) ("Maybe the term "manifest disregard' was meant to name a new ground for review, but maybe it merely referred to the $\S 10$ grounds collectively, rather than adding to them.").

93. See, e.g., Hayford, supra note 10, at 121-22 (stating that the lack of clarity in Wilko has left the law of vacatur in "disarray").

94. Michael A. Scodro, Deterrence and Implied Limits on Arbitral Power, 55 DuKE L. J. 547, 567 (2005) ("Despite its humble origins and lack of explication from the Supreme Court, the 'manifest disregard' doctrine has taken hold in every federal circuit and in many state courts."). The Fifth Circuit, after the Supreme Court's decision in Hall Street, decided that manifest disregard is no longer a ground for vacatur under the FAA. Citigroup Global Mkts., Inc. v. Bacon, 562 F.3d 349, 350 (5th Cir. 2009). The Eleventh Circuit recently took this position as well. Frazier v. CitiFinancial Corp., 604 F.3d 1313, 1314 (11th Cir. 2010). These circuits so far are alone amongst the circuit courts of appeals in reaching this conclusion. See Hiro N. Aragaki, The Mess of Manifest Disregard, 119 YALE L.J. ONLINE 1, 4 (2009), http://yalelawjournal.org/2009/09/29/aragaki.html (explaining that the Second, Seventh, and Ninth Circuits continue to recognize manifest disregard after Hall Street). 
to overturn arbitration awards now rely on manifest disregard more frequently than any other ground for vacatur. ${ }^{96}$ In short, it is widely recognized and widely used as a ground for trying to vacate awards under the FAA.

Yet, the Supreme Court rarely has addressed the doctrine since creating it, ${ }^{97}$ and only recently did the Court give it any substantive analysis. ${ }^{98}$ So lower courts freely applied the doctrine over the last fifty years without any real constraints on its scope or method of application. Naturally, this led to varied applications of the doctrine-some very broad, some extremely narrow, but all attempting to balance arbitration's competing goals of efficiency and accuracy.

The first method of applying manifest disregard is known as the "futility-acknowledged" approach. ${ }^{99}$ It is based on the level of difficulty involved in determining whether an arbitrator has consciously decided to ignore known, applicable law, especially if the arbitrator did not issue a reasoned award. ${ }^{100}$ Courts following this approach will not apply the manifest-disregard doctrine unless direct evidence exists that the arbitrator consciously disregarded the law. ${ }^{101}$ This, obviously, is a

95. Scodro, supra note 94, at 567.

96. See, e.g., LeRoy \& Feuille, supra note 10, at 189 (finding in an empirical study of labor arbitrations that manifest disregard was the most frequently used ground for vacatur); Scodro, supra note 94, at 567 ("Today, parties dissatisfied with arbitral awards routinely seek judicial review on the theory that arbitrators 'manifestly disregarded the law' in reaching their decisions ....").

97. See First Options of Chi., Inc. v. Kaplan, 514 U.S. 938, 942 (1995) (citing Wilko and mentioning manifest disregard in a parenthetical following the cite); Shearson/Am. Express, Inc. v. McMahon, 482 U.S. 220, 231 (1987) (citing Wilko and quoting its sentence on manifest disregard); McMahon, 482 U.S. at 258-59, 268 (Blackmun, J., concurring in part and dissenting in part) (acknowledging manifest disregard and citing Wilko); Mitsubishi Motors Corp. v. Soler ChryslerPlymouth, Inc., 473 U.S. 614, 656 (1985) (Stevens, J., dissenting) (stating that arbitration awards may be overturned if they are in manifest disregard of the law); see also Scodro, supra note 94, at 567 ("A majority of the Supreme Court has only even hinted approval of the doctrine on one occasion since Wilko was decided in 1953.").

98. See Hall St. Assocs. v. Mattel, Inc., 552 U.S. 576, 585 (2008) (expressing a belief that manifest disregard of the law could fall under one of the existing statutory grounds for vacatur under the FAA). I will discuss Hall Street in more detail shortly.

99. Hayford, supra note 10, at 125-26 (citing Prudential-Bache Secs., Inc. v. Tanner, 72 F.3d 234, 240 (1st Cir. 1995); Merrill Lynch, Pierce, Fenner \& Smith, Inc. v. Jaros, 70 F.3d 418, 421 (6th Cir. 1995); Advest, Inc. v. McCarthy, 914 F.2d 6, 10 (1st Cir. 1990)).

100. Id.; see also P.R. Tel. Co. v. U.S. Phone Mfg. Corp., 427 F.3d 21, 32 (1st Cir. 2005) ("Put differently, 'disregard implies that the arbitrators appreciated the existence of a governing legal rule but wilfully [sic] decided not to apply it. As arbitrators need not explain their award, and did not do so here, it is no wonder that appellant is hard pressed to satisfy the exacting criteria for invocation of the doctrine." (citations omitted)), abrogated on other grounds by Hall St., 552 U.S. at 583.

101. Hayford, supra note 10, at 126; see also Scodro, supra note 94, at 570 (noting that most courts will limit the manifest-disregard doctrine to "instances in which "the law is totally clear, the arbitrator understood the law, and chose to ignore it."”). 
severely limited approach; in fact, it essentially makes the doctrine a nullity. ${ }^{102}$ Without a reasoned award, or a transcript of the proceedings showing that the arbitrator explicitly refused to follow the law, it is nearly impossible to convince a court to overturn an award under this standard. ${ }^{103}$ Even worse, if the arbitrator does not know the law, then the arbitrator cannot consciously disregard it. So this standard actually encourages arbitrator ignorance and punishes parties who-through incompetent counsel or lack of counsel altogether-fail to educate the arbitrator on what the law is. ${ }^{104}$ Most courts that recognize manifest disregard as a ground for overturning awards appear to use this approach. $^{105}$

The second method of applying manifest disregard is the "big-error" approach. ${ }^{106}$ As its name implies, this approach does not require direct evidence that the arbitrator consciously disregarded the law; instead, it focuses on whether the arbitrator made an egregious mistake. ${ }^{107}$ In short, it allows a court to overturn an arbitration award by assuming that the arbitrator consciously disregarded known, applicable law based simply on the law's clarity and the arbitrator's failure to apply it. ${ }^{108}$ This is the broadest potential application of the manifest-disregard doctrine and the least frequently used. Any court that uses it does so despite Wilko's

102. Hayford, supra note 10 , at 126.

103. Poser, supra note 33, at 505-06 ("Given the fact that arbitrators seldom write opinions explaining their decisions, there is little likelihood that a losing party in an arbitration will be able to persuade a reviewing court that the arbitrators manifestly disregarded the law.").

104. See id. at 515 ("Because the manifest disregard standard protects an arbitral award from vacatur if the arbitrators did not know the law, it encourages arbitrators not to find out what the law is and at the same time penalizes parties who fail to bring the law to the arbitrators' attention ...."); see also LEONARD L. RISKIN \& JAMES E. WeSTBROOK, DisPUTE RESOlUTION AND LAWYERS 564 (2d ed. 1997) ("Under the 'manifest disregard' standard of review, it appears that a court could confirm an arbitrator's award that was based on an erroneous interpretation of a federal statute as long as the arbitrator did not know that the award conflicted with the statute.").

105. Hayford, supra note 10, at 126; see also 2 LARRY E. EDMONSON, DOMKE ON COMMERCIAL ARBITRATION $\S 39: 8$ (2002) ("[C]ourts generally apply the following two part test in determining if the award should be vacated for manifest disregard of the law: (1) Did the arbitrator know of the governing legal principal yet refused to apply it or ignored it all together? and (2) Was the law ignored by the arbitrators well defined, explicit and clearly applicable to the case.").

106. Hayford, supra note 10, at 127; see also Stephen K. Huber, State Regulation of Arbitration Proceedings: Judicial Review of Arbitration Awards by State Courts, 10 CARDOZO J. CONFLICT RESOL. 509, 562 (2008) (explaining that two potential applications of the manifest-disregard standard are (1) to police outlying awards and (2) to overturn awards that materially vary from judicial results).

107. Hayford, supra note 10, at 127 (citing Willemijn Houdstermaatschappij, BV v. Standard Microsystems Corp., 103 F.3d 9, 12-13 (2d Cir. 1997); Advest, Inc. v. McCarthy, 914 F.2d 6, 10 (1st Cir. 1990)).

108. Id. at $127-28$. 
statement that awards should not be reviewed for "error in interpretation."109

The third application falls somewhere between the first two and is known as the "presumption-based" approach. ${ }^{110}$ Under this approach the court reviews the record of the arbitration proceedings and will overturn the award if something in that record creates a presumption that the arbitrator ignored known, applicable law. ${ }^{111}$ For example, the Eleventh Circuit once overturned an award under the manifest-disregard standard because it disagreed with the arbitrator's legal conclusion and because the prevailing party at the arbitration had "flagrantly and blatantly urged" the arbitrator to ignore the controlling law. ${ }^{112}$ With no written opinion, this was the only available evidence that the arbitrator consciously disregarded the law, but the court thought it was enough to overturn the award. ${ }^{113}$ So, like the futility-acknowledged approach, the presumptionbased approach requires some, albeit limited, proof that the arbitrator knew the law and chose to ignore it. Yet, like the big-error approach, it allows the court to overturn an award without direct proof that the arbitrator made a conscious decision to ignore the law. ${ }^{114}$

All three approaches show that the doctrine is malleable, giving courts flexibility in using it to balance arbitration's efficiency policy against their desire for accurate awards. ${ }^{115}$ But the three approaches also show courts' disagreement over what the appropriate balance between efficiency and accuracy should be. ${ }^{116}$ Courts applying the narrow standard are enforcing arbitration's limited-review principle, which is based on arbitration's efficiency policy. Courts applying the broader standard find inaccurate awards fundamentally unfair. Neither of these extremes is correct when applied uniformly to all types of arbitration; the emphasis placed on efficiency or accuracy should depend on the type of arbitration involved.

109. Wilko v. Swan, 346 U.S. 427, 436-37 (1953), overruled on other grounds by Rodriguez de Quijas v. Shearson/Am. Express, Inc., 490 U.S. 477 (1989).

110. Hayford, supra note 10, at 128-32 (citing Montes v. Shearson Lehman Bros., Inc., 128 F.3d 1456 (11th Cir. 1997); Halligan v. Piper Jaffray, Inc., 148 F.3d 197 (2d Cir. 1998)).

111. Id. at 129-30 ("The framework for analysis under this third model works backwards from an arbitral outcome the reviewing court believes to be flawed as a matter of law, confirmed by an exhaustive evaluation of the factual record made in arbitration.").

112. Montes, 128 F.3d at 1461.

113. Id. at 1461-62; Hayford, supra note 10, at 129.

114. See Hayford, supra note 10, at 125-32 (comparing all three approaches).

115. Scodro, supra note 94 , at 571 .

116. See id. at 571-72 (discussing "modern doctrinal inconsistencies" resulting from judicial attempts at balancing). 
The Supreme Court, however, apparently disagrees. For example, it has consistently said that arbitration awards should not be reviewed for legal error. ${ }^{117}$ The Court's intent, undoubtedly, has been to promote arbitration's efficiency policy. But the uniform application of this "no legal error" rule to all arbitrations fails to recognize that not all arbitrations are alike. And it excessively limits other courts' abilities to overturn awards under the manifest-disregard standard in mandatory arbitrations. Thus, it exhibits the contradiction between arbitration's goal of accurate awards and the absence of any meaningful judicial review to achieve that goal. ${ }^{118}$

\section{B. Manifest Disregard, Legal Error, and the Supreme Court}

The Supreme Court substantively addressed manifest disregard for the first time in 2008 in Hall Street Associates v. Mattel, Inc., ${ }^{119}$ and its decision created some confusion over the doctrine's scope and continued existence. The Court granted certiorari in Hall Street to resolve a circuit split over whether parties can contractually expand the grounds for vacatur under the FAA, not to address manifest disregard. ${ }^{120}$ But one passage in Hall Street addressed manifest disregard's origins, and it expressed - albeit not in great detail - the Court's limited view of how lower courts should apply the doctrine. ${ }^{121}$ To explain this passage, a brief aside on the case itself is necessary.

Hall Street sued Mattel in federal court over two issues: (1) whether Mattel had complied with applicable environmental laws during the term of the parties' lease and (2) whether Mattel properly terminated that lease. ${ }^{122}$ But during the course of the litigation, the parties agreed to

117. See supra note 105 and accompanying text. In addition to the Wilko Court's statement regarding no judicial review for "error in interpretation," also see Major League Baseball Players Ass'n v. Garvey, 532 U.S. 504, 509 (2001) (stating that "serious error" by the arbitrator does not warrant vacating an award).

118. Poser, supra note 33, at 504-05 ("The judicially created 'manifest disregard' ground for vacatur represents an attempt by the federal courts to resolve the inherent contradiction between the goal that arbitrators faithfully and accurately apply the law and the absence of meaningful judicial review to enforce this goal.").

119. 552 U.S. 576 (2008).

120. Id. at 578. The question presented in the petition for certiorari was whether "the Federal Arbitration Act ('FAA') precludes a federal court from enforcing the parties' clearly expressed agreement providing for more expansive judicial review of an arbitration award than the narrow standard of review otherwise provided for in the FAA[.]" Petition for Writ of Certiorari at i, Hall St., 552 U.S. 576 (No. 06-989) 2007 WL 128611.

121. Hall St., 552 U.S. at $584-85$.

122. Id. at 579 . 
arbitrate their disagreement over Mattel's environmental compliance. ${ }^{123}$ The agreement stated that the district court - the same court that was hearing the lease-termination dispute-could vacate or modify the arbitrator's award if the arbitrator's conclusions of law were "erroneous." "24 This, of course, is not one of the statutory grounds for vacatur under the FAA. ${ }^{125}$ So, by contracting for review of legal error, the parties had attempted to contractually expand the court's ability to vacate awards. ${ }^{126}$

When the arbitrator ruled in favor of Mattel, Hall Street appealed the ruling to the district court, which overturned the award (based on legal error) and remanded to the arbitrator for further consideration. ${ }^{127}$ Then, after the arbitrator ruled in favor of Hall Street on remand, both parties sought to modify the award. ${ }^{128}$ The district court, however, allowed it to stand. ${ }^{129}$ Each party then appealed to the Ninth Circuit, where Mattel argued for the first time that the district court erred when it reviewed the arbitrator's award for legal error. ${ }^{130}$ Citing a recent Ninth Circuit en banc opinion, Mattel argued that the arbitration provision was unenforceable. $^{131}$ The Ninth Circuit ultimately agreed. ${ }^{132}$ Hall Street then filed a petition for certiorari with the Supreme Court, which the Court granted to "decide whether the grounds for vacatur and modification provided by $\S \S 10$ and 11 of the FAA are exclusive."133

In appealing the Ninth Circuit's decision, Hall Street made two arguments. First, it argued that the provision allowing review for legal error was valid because arbitration is a "creature of contract." 134 The

123. Id.

124. Id.

125. See 9 U.S.C. $§ 10$ (a) (2006) (stating that a court may vacate an arbitration award where (1) the winning party procured the award by corruption or fraud, (2) the arbitrators were biased or corrupt, (3) the arbitrators were guilty of misconduct, or (4) the arbitrators exceeded their powers).

126. Hall St., 552 U.S. at 579.

127. Id. at 580 .

128. Id.

129. Id. The district court did modify the arbitrator's interest calculation, but that was the only change made. $I d$.

130. Id.

131. Id.

132. Id. at 581 .

133. Id. The Court's use of the term "exclusive" is what has created much of the controversy surrounding manifest disregard because some courts, including the Fifth Circuit, have interpreted that language to mean that nonstatutory grounds for vacatur no longer exist. Aragaki, supra note 94, at 3-4. As I explain in note 140, I disagree with that interpretation.

134. Hall St., 552 U.S. at 585. 
Court found this argument insufficient. ${ }^{135}$ More importantly, Hall Street's second argument was "that expandable judicial review authority has been accepted as the law since Wilko v. Swan." 136 The Court ultimately dismissed this argument as well, saying that although Wilko "includes some language arguably favoring Hall Street's position, arguable is as far as it goes." "137

In discussing the latter argument, the Court quoted Wilko's manifestdisregard statement and mentioned that Hall Street interpreted this statement as allowing parties to contract for expanded judicial review. ${ }^{138}$ Disagreeing with Hall Street's interpretation, the Court pointed out that manifest disregard is a judicially created ground for vacatur and that parties cannot expand the grounds for judicial review just because judges can. ${ }^{139}$ The Court then said that the Wilko statement "expressly rejects just what Hall Street asks for here, general review for an arbitrator's legal errors." 140 But that was the extent of the Court's attempt to define

135. Id. at 586 ("[W]e think the argument comes up short.”). More specifically, the Court agreed that parties are free to contract regarding issues like choice of arbitrator or choice of substantive law; however, it said that the text of the FAA compels a finding that the grounds in $\S \S 10$ (for vacatur) and 11 (for modification) are exclusive. Id.

136. Id. at 584 .

137. Id.

138. Id. at $584-85$.

139. Id. at 585. The Court did not explain this argument very well, as it failed to explicitly explain that manifest disregard is a judicially created ground for vacatur. Rather, it left this fact implied in its following statement: "Hall Street sees this supposed addition to $\S 10$ as the camel's nose: if judges can add grounds to vacate (or modify), so can contracting parties." Id.

140. Id. at 585. The Court also added to the confusion over the foundation of the doctrine. Specifically, the Court called Wilko's manifest-disregard statement "vague" and then it said: "Maybe the term 'manifest-disregard' was meant to name a new ground for review, but maybe it merely referred to the $\S 10$ grounds collectively, rather than adding to them. Or, as some courts have thought, "manifest-disregard' may have been shorthand for $\S 10(\mathrm{a})(3)$ or $\S 10(\mathrm{a})(4) \ldots$..." Id. (citations omitted). The Fifth Circuit has interpreted Hall Street as eliminating manifest disregard as a ground for vacating awards under the FAA. See Citigroup Global Mkts., Inc. v. Bacon, 562 F.3d 349 (5th Cir. 2009). The Eleventh Circuit followed suit in 2010. Frazier v. CitiFinancial Corp., 604 F.3d 1313, 1314 (11th Cir. 2010). The Second and Ninth Circuits have determined that manifest disregard still stands as a ground for vacatur under the FAA. See Stolt-Nielsen SA v. AnimalFeeds Int'l Corp., 548 F.3d 85 (2d Cir. 2008), rev'd on other grounds, 130 S. Ct. 1758 (2010); Comedy Club, Inc. v. Improv W. Assocs., 553 F.3d 1277 (9th Cir. 2009). The Supreme Court was expected to clarify the continued existence of the doctrine when it issued its opinion in the appeal of the Second Circuit's decision in Stolt-Nielsen, but the Court expressed no opinion on "whether 'manifest disregard' survives." See 130 S. Ct. at 1768 n.3.

I don't believe Hall Street eliminated manifest disregard. Rather, like Professor Aragaki, I believe that Hall Street simply prohibits parties from contractually expanding judicial review. See Aragaki, supra note 94, at 5 (arguing that courts should interpret the holding of Hall Street - that the statutory grounds for vacatur are exclusive - to simply mean that parties cannot expand the grounds for vacatur by contract). But even if the Fifth and Eleventh Circuits and other elimination theorists are correct in stating that, after Hall Street, manifest disregard no longer exists as a ground 
manifest disregard; it gave no other indication of the scope of the doctrine. ${ }^{141}$ Thus, the Court simply noted what manifest disregard does not mean, not what it does. ${ }^{142}$

The reason for the Court's minimalist approach is unclear. Maybe it failed to define the scope of the doctrine because that was the only way to garner a majority vote. ${ }^{143}$ Or maybe it avoided the issue because the right to contractual expansion was the actual issue raised by the parties. ${ }^{144}$ Regardless, the Court's statement that manifest disregard does not include review for legal error is out there, and it appears to be consistent with what the Wilko Court intended manifest disregard to mean. ${ }^{145}$ But that does not mean it is correct or that the statement is broad enough to preclude review for legal error in all types of arbitration. ${ }^{146}$ In fact, the Court's manifest-disregard jurisprudence may

for vacatur and even if Congress fails to codify manifest disregard any time in the near future, state courts will still have the opportunity to redefine the doctrine, as some states have adopted manifest disregard as a ground for vacatur under their state arbitration acts. See infra note 150. In fact, state courts may be a good testing ground for my proposal to see how efficiently it works. See Huber, supra note 106, at 563 ("In the absence of agreement about what is desired from the concept of manifest disregard of the law, whether under that name or an alternative rubric, no good answer is available. This is a situation tailor-made for state law experimentation.").

141. The Court subsequently granted the petition for certiorari in a case out of the Ninth Circuit where the lower court had overturned an arbitration award under the manifest-disregard standard. See Improv W. Assocs. v. Comedy Club, Inc., 129 S. Ct. 45, 45 (2008). But it did not take the opportunity to clarify manifest disregard in that case. Id. Instead it simply remanded to the Ninth Circuit with instructions to reconsider the decision in light of Hall Street. Id. On remand, the Ninth Circuit found that Hall Street had no effect on its decision because it already considered manifest disregard part of the statutory grounds for vacatur under the FAA. Comedy Club, Inc. v. Improv W. Assocs., 553 F.3d 1277, 1290 (9th Cir. 2009).

142. See Hall St., 552 U.S. at 585-86 (discussing manifest disregard).

143. Robert Ellis, Imperfect Minimalism: Unanswered Questions in Hall Street Associates, L.L.C. v. Mattel, Inc., 128 S. Ct. 1396 (2008), 32 HARV. J.L. \& PuB. POL'Y 1187, 1192 (2009) ("It is conceivable that the Court refused to define manifest disregard in order to ensure the broadest possible agreement for its decision.").

144. See Cass R. Sunstein, Foreword: Leaving Things Undecided, 110 Harv. L. ReV. 6, 6 (1996) ("Frequently judges decide no more than they have to decide. They leave things open. They make deliberate decisions about what should be left unsaid. This practice is pervasive: doing and saying as little as necessary to justify an outcome.").

145. The Wilko Court also said that awards should not be reviewed for legal error. Wilko v. Swan, 346 U.S. 427, 436-37 (1953), overruled on other grounds by Rodriguez de Quijas v. Shearson/Am. Express, Inc., 490 U.S. 477 (1989). And the sources cited by the Court in support of its original "manifest disregard" statement actually conflict with the doctrine as it exists today. See Scodro, supra note 94, at 581-86 (stating that the sources cited in Wilko supported vacating an award "when the arbitrator manifested an intention to adhere to the law but erred in executing this intention, not when the arbitrator consciously disregarded legal rules, as the modern 'manifest disregard' standard allows.").

146. See Tara Leigh Grove, The Structural Case for Vertical Maximalism, 95 CORNELL L. REv. 1,3 (2009) ("[W]hen a minimalist court establishes a narrow legal rule to govern its own case, it leaves other courts in other cases free to make their own rules of law."). 
be vague enough for future courts to step around the "no legal error" limitation, at least in noncommercial arbitrations. ${ }^{147}$ Part III explains why they should do so.

\section{Creating a New CASE-Centric Model for Applying Manifest DISREGARD}

Given the Supreme Court's failure to clarify manifest disregard's scope in Hall Street, the doctrine still has at least four significant flaws, all of which impact mandatory arbitration's procedural justice. First, as previously mentioned, it has no firm basis in law. The Supreme Court created the doctrine in dicta in a case that it subsequently overturned, ${ }^{148}$ and it expressed uncertainty over the doctrinal foundation in Hall Street. ${ }^{149}$ Although this is a significant flaw, it has been amply addressed elsewhere in the literature. ${ }^{150}$ For now, I will focus on the other three, which are (1) that the doctrine remains largely undefined, (2) that the definition we have is too limited, and (3) that courts apply the doctrine uniformly regardless of the nature of the arbitration. Then, after explaining the nature and effects of the flaws in the current doctrine, I propose a new method for applying it - one that allows courts to review awards for legal error in mandatory arbitrations. This new case-centric method will make mandatory arbitration more palatable by enhancing procedural justice for the parties forced into it. And it will move us toward recognizing that not all arbitrations should be treated alike.

147. Because Hall Street involved two commercial parties, you could read its statement on legal error and manifest disregard in that context and decide that the statement applies only to commercial arbitrations. Admittedly, however, you could also read it as a blanket statement precluding review for legal error in all arbitrations, and you could cite Wilko in support of such a reading-because Wilko was not a commercial arbitration and because it also said awards could not be reviewed for legal error. But, as I explain in Part IV, it makes more sense to allow review for legal error in mandatory arbitrations and to not allow review for legal error in commercial arbitrations.

148. Wilko, 346 U.S. at $436-37$.

149. Hall St. Assocs. v. Mattel, Inc., 552 U.S. 576, 585 (2008); see also supra note 140.

150. Christopher Drahozal recently published a well-reasoned piece on this topic suggesting that Congress should codify manifest disregard as a ground for vacatur under the FAA-I recommend it if you wish to read more about that specific problem. See Christopher R. Drahozal, Codifying Manifest Disregard, 8 NEV. L.J. 234, 235 (2007) ("Without manifest disregard review, a court may face the prospect of having to confirm an arbitration award in which the arbitrators on the face of the award blatantly refuse to apply clearly applicable law."). However, I should note that I disagree with the limited nature of the manifest-disregard standard that Drahozal supports. On a related note, at least one state arbitration act recognizes manifest disregard as a statutory ground for vacatur. The Georgia General Assembly codified manifest disregard as a ground for vacatur under Georgia's arbitration act in 2003. GA. CODE ANN. § 9-9-13(b)(5) (West Supp. 2009). 


\section{A. The Doctrine Remains Largely Undefined}

Manifest disregard's meaning still is unclear. When the Supreme Court mentioned manifest disregard in Wilko, it did so with little explanation of what the phrase meant. ${ }^{151}$ And the Court didn't elaborate on how to interpret that phrase until issuing its opinion in Hall Street more than fifty years later. ${ }^{152}$ Even then, the Court took a minimalist approach to addressing the doctrine by telling us what manifest disregard does not mean instead of what it does. ${ }^{153}$ Specifically, the Court said that the doctrine does not allow courts to review awards for legal error; it failed, however, to otherwise explain the doctrine's scope. ${ }^{154}$ So it remains undefined, which is why lower courts have been free over the last fifty years to create their own definitions. ${ }^{155}$ This is, at least in part, why parties have relied on manifest disregard so frequently over the last half century when attempting to overturn arbitration awards.

This lack of definition means that we will continue to have no uniform standard across jurisdictions for applying the doctrine. As a result, parties will be subject to different standards based on the jurisdiction in which their arbitration takes place. ${ }^{157}$ This may lead to forum shopping by parties sophisticated enough to include the more favorable jurisdictions in their forum-selection clauses. ${ }^{158}$ Moreover, it diminishes perceptions of procedural justice in arbitration because parties prefer defined procedures. ${ }^{159}$ Specifically, even if manifest disregard has

151. 346 U.S. at 436-37 ("In unrestricted submissions, ... the interpretations of the law by the arbitrators in contrast to manifest disregard are not subject, in the federal courts, to judicial review for error in interpretation.").

152. 552 U.S. at $584-85$.

153. See Ellis, supra note 143, at 1192 (discussing the minimalist approach of the Hall Street majority).

154. Hall St., 552 U.S. at 584-85.

155. Scodro, supra note 94 , at 567.

156. LeRoy \& Feuille, supra note 10, at 203-05 ("Inconsistent approaches over the manifest disregard standard appear to spur the surprising popularity of this basis for challenging awards.").

157. Hayford, supra note 10, at 125-26 (summarizing different manifest-disregard standards currently applied by various courts).

158. Those parties, for example, might avoid forums within the Second Circuit, which currently seems more inclined than most other circuits to review awards for legal error. See, e.g., Willemijn Houdstermaatschappij, BV v. Standard Microsystems Corp., 103 F.3d 9, 13 (2d Cir. 1997) ("[A] court may infer that the arbitrators manifestly disregarded the law if it finds that the error made by the arbitrators is so obvious that it would be instantly perceived by the average person qualified to serve as an arbitrator.").

159. Shestowsky, supra note 81 , at 236, 241-42 (finding through three experiments that parties prefer rules that are pre-established). 
a set meaning in each jurisdiction, when parties fight over the appropriate jurisdiction, it is unclear which manifest-disregard doctrine will apply. ${ }^{160}$

Finally, the lack of definition is troublesome because it has persisted for so long. More than fifty years have passed since the Supreme Court created manifest disregard in 1953. So, for more than fifty years, parties have been fighting over the meaning of this standard. And the Supreme Court's recent decision addressing manifest disregard will only increase the number of disputes involving the doctrine. ${ }^{161}$ Perhaps finally defining it will reduce the use of resources necessary to resolve these disputes and will improve parties' perceptions of mandatory arbitration's procedural fairness.

\section{B. Not All Arbitrations Are Alike}

Arbitration is designed to be an efficient process-limited discovery, limited rules of evidence, and limited review of awards. ${ }^{162}$ But its emphasis on efficiency should not remain constant for all types of arbitration. ${ }^{163}$ The simple reason is that not all arbitrations are alike. Mandatory arbitration, for example, is a recent phenomenon-a result of the Supreme Court's "national policy favoring arbitration" jurisprudence. ${ }^{164}$ It involves commercial parties who use their superior bargaining power to contractually bind consumers, employees, franchisees, patients, and others to resolve disputes outside of court. ${ }^{165}$

160. See John W. Hinchey \& Thomas V. Burch, The Effect of Forum-Selection Clauses on a District Court's Power to Compel Arbitration, DisP. Resol. J., Nov. 2005-Jan. 2006, at 55, 55 (explaining the difficulties that arise when a party files a motion to compel in a jurisdiction outside the one called for in the applicable forum selection clause).

161. See Aragaki, supra note 94, at 1-2 (noting that state or federal courts, in the year following Hall Street, faced decisions on manifest disregard on average once a week).

162. See Stephen L. Hayford, Law in Disarray: Judicial Standards for Vacatur of Commercial Arbitration Awards, 30 GA. L. REV. 731, 740 (1996) (stating that parties who agree to arbitrate trade procedures and judicial review for simplicity and expediency); Thomas J. Stipanowich, Arbitration: The "New Litigation", 2010 U. ILL. L. REV. 1, 4 ("Conventional wisdom suggests that businesses choose binding arbitration mainly because it is perceived to be different from litigation. Parties look for some or all of the following: cost savings, shorter resolution times, a more satisfactory process, expert decision makers, privacy and confidentiality, and relative finality.").

163. See Sarah Rudolph Cole, Uniform Arbitration: "One Size Fits All” Does Not Fit, 16 Оніо ST. J. ON DISP. RESOL. 759, 780 (2001) (calling for "separate arbitration acts—one designed to offer procedural protections to one-shot players and the other to protect the integrity of the traditional arbitral process"); see also BRUNET ET AL., supra note 75, at 3 (stating that "policies relating to expertise, efficiency, and finality are often trumped by higher order principles that support arbitration").

164. Sternlight, supra note 5, at 1636.

165. See id. at $1638-39$. 
There is no bilateral consent. ${ }^{166}$ In fact, sometimes commercial parties are able to bind others to arbitration without having them sign an arbitration agreement. ${ }^{167}$ The purpose is to lock them into a less formal method of adjudicating disputes where they have little chance of challenging a legally inaccurate award and where the commercial parties have repeat player advantages. ${ }^{168}$

Purely commercial arbitrations, on the other hand, have a much longer history and involve parties with relatively equal bargaining power that freely agree to arbitrate their claims. ${ }^{169}$ The parties make an economic decision to forego the more involved, time-consuming litigation process because they value the potential efficiency of arbitration. ${ }^{170}$ Efficiency is more important in this context than whether any given award is accurate. Inaccurate awards balance out over time because of these parties' repeat player status. ${ }^{171}$

Congress intended the FAA to cover purely commercial arbitrations, ${ }^{172}$ as it did not want arbitration agreements to be "offered on a take-it-or-leave-it basis to captive customers or employees." "173 It based

166. See BRUNET ET AL., supra note 75, at 6-7 ("Bilateral consent to arbitrate is essential to autonomy and to freedom. If only one party wants arbitration, the other party loses control."); Reuben, supra note 47, at 282 (stating that involuntary arbitration "frustrates the larger goals of democratic governance").

167. Sternlight, supra note 5, at 1640 ("Thus, companies often impose arbitration on their consumers by including an arbitration agreement in a document that is received by the consumer but not necessarily read and certainly not signed.").

168. Id. at 1650-51 ("Whereas a given company will tend to arbitrate many consumer disputes, a given consumer or employee will typically arbitrate, at most, one. Thus, the companies have far greater experience with and exposure to the arbitration process than do the consumers or employees.").

169. See id. at 1635 (discussing how businesses have traditionally used arbitration to settle disputes); Cole, supra note 163, at 773 (discussing the dynamics of arbitration agreements between repeat players).

170. Sternlight, supra note 5, at 1635. Businesses also look for privacy and arbitrator expertise. Id.

171. Cole, supra note 163, at 775 ("Moreover, for repeat players, it is irrelevant that errors may occur in determining the outcome of a particular dispute, as long as no systematic bias presents itself. Repeat players are aware that outcomes should balance out over the long term.").

172. For example, during a floor debate on the FAA the Chairman of the House Committee on the Judiciary said: "This bill simply provides for one thing, and that is to give an opportunity to enforce an agreement in commercial contracts and admiralty contracts - an agreement to arbitrate, when voluntarily placed in the document by the parties to it." 65 CONG. REC. 1931 (1924); see also Bills to Make Valid and Enforceable Written Provisions or Agreements for Arbitration of Disputes Arising out of Contracts, Maritime Transactions, or Commerce Among the States or Territories or with Foreign Nations: Joint Hearings on S. 1005 and H.R. 646 Before the Subcomms. of the Comms. on the Judiciary, 68th Cong. 14-15 (1924) (statements of Sen. Sterling, Chairman, Subcomm. of the Comm. on the Judiciary and Julius H. Cohen, General Counsel, New York State Chamber of Commerce) (addressing concerns over take-it-or-leave-it arbitration agreements).

173. Sternlight, supra note 5, at 1636 (quoting Prima Paint Corp. v. Flood \& Conklin Mfg. Co., 
its reasoning on the fairness principle. Specifically, when parties enter into an arbitration agreement, the agreement's fairness is assessed in one of two ways: looking at the conditions underlying the agreement's formation or looking at the substantive fairness of the agreement itself. ${ }^{174}$ Under either view, the parties who are subjected to mandatory arbitration do not receive a fair exchange. They have little choice in deciding whether to accept the arbitration clause-if they even know it is in their agreement - and the agreement itself is drafted to favor the commercial party. ${ }^{175}$ Congress recognized the potential inequity of allowing mandatory arbitration under these circumstances, which is why it intended the FAA to apply to commercial arbitrations. ${ }^{176}$

So far, courts have failed to fully recognize Congress's intent and, more generally, have failed to recognize that not all arbitrations should be treated alike. ${ }^{177}$ For example, regardless of what manifest-disregard standard a particular jurisdiction chooses to apply, it applies that standard uniformly to all arbitrations. ${ }^{178}$ So courts within that jurisdiction apply the same standard to mandatory arbitrations and commercial arbitrations alike. ${ }^{179}$ This one-size-fits-all approach to the manifest-disregard standard is a mistake. ${ }^{180}$ It either tends to promote efficiency at the

388 U.S. 395, 414 (1967) (Black, J., dissenting)). In Prima Paint, Justice Black said: "The members of Congress revealed an acute awareness of this problem. On several occasions they expressed opposition to a law which would enforce even a valid arbitration provision contained in a contract between parties of unequal bargaining power." 388 U.S. at 414.

174. Michael J. SANDel, Liberalism AND the Limits of Justice 106 (2d ed. 1998).

175. See Cole, supra note 163, at 768-70.

176. See Sternlight, supra note 5, at 1636; see also Cole, supra note 163, at $764 \mathrm{n} .21$ (describing statements made in the floor debate before the vote on the FAA indicating that Congress intended the FAA to apply to commercial disputes).

177. This is a byproduct of the Supreme Court's national policy favoring arbitration and its steady expansion of claims that parties may be forced to arbitrate.

178. See Cole, supra note 163 , at 759 .

179. The term "mandatory arbitration" is somewhat controversial, as some arbitration scholars believe it unfairly characterizes arbitration agreements signed by consumers, employees, or franchisees. See Sternlight, supra note 5, at $1632 \mathrm{n} .1$ (citing authors who disagree with the nomenclature). I previously defined mandatory arbitration as, among other things, any arbitration where a party, including a commercial party, with grossly unequal bargaining power is required through contract to arbitrate a dispute. See supra note 3. I admit that this definition seems troublesome in terms of the proposal I make in this paper on at least two counts. First, determining whether unequal bargaining power exists will require a fact-based inquiry by the court reviewing the arbitration award, which will increase the expense of the arbitration. Second, including commercial parties within this definition will present situations where such a party, even though it has unequal bargaining power, may be sophisticated enough to make an informed economic decision regarding whether to sign the arbitration agreement. Nevertheless, the definition I provide should work in the mandatory-arbitration context.

180. See Cole, supra note 163, at 759 (arguing that it is a mistake to treat arbitration as a "one size fits all dispute resolution mechanism"); Stipanowich, supra note 162, at 39 n.289 ("One-size- 
expense of parties who had little choice in deciding whether to arbitrate their claims, or it increases costs for parties who chose arbitration intending it to be an efficient way to resolve disputes. ${ }^{181}$ Thus, it fails to recognize that parties forced into arbitration may want, and deserve, greater procedural protections than commercial parties who made an economic decision to arbitrate. ${ }^{182}$

Courts should place more emphasis on accuracy in mandatory arbitration by expanding manifest disregard to cover situations where arbitrators make a legal error-whether intentional or not. The narrow definition that most courts currently apply excessively limits judges' ability to correct arbitrators' mistakes. ${ }^{183}$ This means that parties subjected to mandatory arbitration have no control over correcting an award when an arbitrator unintentionally disregards the law, which is particularly troublesome given that arbitrators often fail to follow the law. ${ }^{184}$ The procedural justice literature shows that parties like decision control; in particular, parties want the ability to appeal arbitrators' decisions. ${ }^{185}$ Mandatory arbitration seems like the ideal context to experiment with giving parties that control, particularly given the recent public campaigns against mandatory arbitration that have focused on arbitration's limited-review principle. ${ }^{186}$ Consequently, it is time to redefine manifest disregard to give more control to parties subjected to mandatory arbitration.

fits-all approaches [to arbitration] are outmoded and intrinsically problematic." (quoting Thomas Stipanowich, Future Lies Down a Number of Divergent Paths, DISP. RESOL. MAG., Spring 2000, at 16, 16)).

181. See Stipanowich, supra note 162 , at $38-39$; see also Huber, supra note 106 , at 562 ("Applying a single standard of legal review to all arbitration awards seems to provide too much review in some instances, but too little review in others [sic] instances.").

182. Treating all arbitrations alike may also tend to harm commercial arbitration in this sense: given the recent push against mandatory arbitration, overreaching reform proposals that do not differentiate between mandatory and commercial arbitrations may unnecessarily carry over to the commercial realm. See Stipanowich, supra note 162, at 40 ("In another of the ironic twists that permeate the history of modern arbitration, pro-arbitration policy and classic contract theory combined to bring standardized employment and consumer agreements alongside commercial agreements for enforcement purposes, provoking responses that sometimes carry over into the commercial realm."); see also Cole, supra note 163, at 759 ("Proponents of a unified approach to arbitration fail to recognize that increasing process to protect employees and consumers may impose burdens on other groups, such as merchants, where those burdens are not warranted.").

183. The narrow definition "nullifies" the doctrine. See Hayford, supra note 10, at 126.

184. Stephen J. Ware, "Opt-In" for Judicial Review of Errors of Law Under the Revised Uniform Arbitration Act, 8 AM. REV. INT’L ARB. 263, 263 (1997) (“'A]rbitrators often do not apply the law."). But see Drahozal, supra note 9, at 190 (stating that empirical evidence doesn't support the idea that arbitration is "lawless").

185. See Folger, supra note 40, at 63-69 (summarizing studies showing that giving parties decision control through appeal mechanisms enhances procedural justice).

186. See sources cited supra notes 5, 11 . 


\section{A Case-Centric Method for Applying Manifest Disregard}

Around the time the Supreme Court announced its "national policy favoring arbitration" in $1984,{ }^{187}$ it began expanding the scope of arbitrable claims to include public-law disputes that previously were offlimits to arbitration. ${ }^{188}$ Now virtually all claims are arbitrable, which allows parties to "privatize" public law and transform mandatory rules to default rules by requiring arbitration of their disputes. ${ }^{189}$ Andrew Guzman has criticized the expansion because allowing parties to contract around mandatory rules inappropriately externalizes costs, reduces social welfare, and circumvents the will of Congress. ${ }^{190}$ And Stephen Ware has suggested expanding protections against erroneous arbitration awards by requiring de novo review of all arbitration decisions involving mandatory rules. ${ }^{191}$ I agree with Guzman's criticisms, and Ware's suggestion would work well in commercial arbitrations-for instance, antitrust disputes. But in mandatory arbitration, the procedural protections should expand even further, giving parties who have not truly consented to arbitration more outcome control.

Specifically, courts should review all awards in mandatory arbitration for legal error under the manifest-disregard standardregardless of whether those awards involve mandatory rules or default rules. This allows courts to review awards based on the parties involved, not on whether mandatory or default rules are at stake. In other words, courts would examine the parties' relationship to determine whether this expanded standard would apply. Based on how I previously defined mandatory arbitration, ${ }^{192}$ the expanded standard would apply to employment disputes, consumer disputes, franchisee disputes, civil rights

187. Southland Corp. v. Keating, 465 U.S. 1, 10 (1984).

188. Ware, supra note 59, at 712-19. These previously inarbitrable claims included claims under RICO, ERISA, Title VII, and ADEA, among others. Id. at 714.

189. Id. at 705-07, 715. Ware defines default rules as "those government-created rights and duties that are privatizable, rules that govern unless the parties contract out of them." Id. at 706 . He defines mandatory rules as "those government-created rights and duties that cannot be avoided by contract, those that are not privatizable." Id.

190. See, e.g., Andrew T. Guzman, Arbitrator Liability: Reconciling Arbitration and Mandatory Rules, 49 DUKE L.J. 1279, 1285, 1298 (2000) ("Arbitration, coupled with limited judicial review, frustrates the intent of lawmakers to make certain legal rules mandatory.").

191. See, e.g., Ware, supra note 59, at 704 ("The [Supreme] Court must either reverse its decisions that claims arising under otherwise mandatory rules are arbitrable, or require de novo judicial review of arbitrator's legal rulings on such claims.”). As an alternative, Andrew Guzman suggested that parties should be able to sue arbitrators who fail to apply mandatory rules. See Guzman, supra note 190, at 1283.

192. See supra note 3. 
disputes, and disputes where the parties have grossly unequal bargaining power. ${ }^{193}$ The narrow standard that most courts currently apply would still apply to purely commercial arbitrations.

Parties may still contract around default rules under my proposal, and arbitrators would have to apply the contractual terms with their applications being reviewed for legal error-that is, the arbitrator must apply the parties' private law. ${ }^{194}$ This preserves some power to the party drafting the arbitration agreement because it can draft around default rules that would otherwise apply. While this would allow commercial parties to contract around rules that may benefit consumers, employees, and others who are subjected to mandatory arbitration, any attempt to contract around default rules would be reviewed under the unconscionability standard, meaning that the drafting party cannot abuse its power. ${ }^{195}$ Also, courts should not allow parties to contract around the right to confirm, vacate, or modify an award, nor should they allow parties to contractually eliminate the reviewing court's ability to award costs or fees. ${ }^{196}$ This would prevent the drafting party from contractually avoiding the rule proposed here. Finally, arbitrators would be obligated to apply default rules that parties have not contracted around. Any failure to apply those rules would be subject to review for legal error, thus increasing parties' ability to rely on a prescribed set of rules.

These changes would protect parties subjected to mandatory arbitration from corporate overreaching and give them the opportunity to correct arbitrators' mistakes. In other words, the changes would increase decision control, thus enhancing procedural justice. ${ }^{197}$ The changes also are justified given the recent push against mandatory arbitration. ${ }^{198}$

193. This is similar to the standard found in some of the recent legislation seeking to prohibit mandatory arbitration altogether. See, e.g., Arbitration Fairness Act of 2007, H.R. 3010, 110th Cong. $\S \S 3(5), 3(6), 4(4)$ (b) (1st Sess. 2007). The only difference is that I would have courts apply the catch-all "unequal bargaining power" provision only in cases of grossly unequal bargaining power.

194. This admittedly goes against the Supreme Court's admonishment that courts should not review arbitrators' contractual interpretations for error. See Major League Baseball Players Ass'n v. Garvey, 532 U.S. 504, 509-10 (2001).

195. See Doctor's Assocs. v. Casarotto, 517 U.S. 681, 686-87 (1996) (“[T]he text of $\S 2$ declares that state law may be applied 'if that law arose to govern issues concerning the validity, revocability, and enforceability of contracts generally.' Thus, generally applicable contract defenses, such as fraud, duress, or unconscionability, may be applied to invalidate arbitration agreements without contravening § 2.” (quoting Perry v. Thomas, 482 U.S. 483, 492 n.9 (1987))).

196. This is similar to the rule under the Revised Uniform Arbitration Act. See UnIF. ARB. Act $\S 4(2000)$.

197. Folger, supra note 40, at 68 ("On balance, it seems warranted to conclude that direct outcome control enhances procedural justice.").

198. See sources cited supra note 5. 
Specifically, consider how public sentiment against mandatory arbitration has continued to grow over the last twenty years. Consumers, employees, franchisees, patients, and others who are subjected to mandatory arbitration are increasingly arguing that it is not fair to require resolution of their claims in a forum where little, if any, chance for error correction exists. ${ }^{199}$ They have even convinced some members of Congress to support an outright ban on mandatory arbitration. ${ }^{200}$ Because the procedural-justice literature shows us that parties' subjective viewpoints matter, those viewpoints should influence the design of an appropriate manifest-disregard standard. ${ }^{201}$ The standard proposed here considers those viewpoints.

Multiple possible objections to this proposal exist. For example, some might think that it inhibits freedom of contract. ${ }^{202}$ Parties generally sign arbitration agreements because they want to avoid the formal litigation process, and allowing review for legal error in mandatory arbitration makes it more likely that parties will nevertheless have to litigate their claims in court. ${ }^{203}$ Consequently, my proposed change also goes against the supposed "essential feature" of arbitration-finality. ${ }^{204}$ Businesses might be less inclined to include arbitration clauses in their standardized contracts if consumers, employees, and others who are forced into arbitration have greater rights to appeal. ${ }^{205}$ Such a change

199. See sources cited supra note 11.

200. See sources cited supra note 5; see also Civil Rights Procedures Protection Act of 1997, S. 63, 105th Cong. (1st Sess. 1997) (calling for a prohibition on mandatory arbitration for civil rights claims).

201. See Shestowsky \& Brett, supra note 37 , at 71 .

202. Sternlight, supra note 5, at 1634 ("Some of these defenders [of mandatory arbitration] also assert that voiding the contract would deny consumers/employees their freedom of contract." (citing Stephen J. Ware, Arbitration Under Assault: Trial Lawyers Lead the Charge, POL'Y ANALYSIS, April 18, 2002, at 1, 8, available at http://www.cato.org/pubs/pas/pa433.pdf)); see also Paul F. Kirgis, The Contractarian Model of Arbitration and Its Implications for Judicial Review of Arbitral Awards, 85 OR. L. REV. 1, 5 (2006) ("Courts venerate party autonomy. They tend to see extreme deference to arbitral awards as necessary to protect the parties' choice of arbitration as an alternative to adjudication.").

203. See Kirgis, supra note 202, at 2 ("The disputants who favor arbitration are not necessarily averse to law and legal solutions, and they typically embrace lawyers as dispute resolution professionals. What they often want to avoid is the formality of traditional adjudicative process.").

204. See Hayford, supra note 10, at 118 (stating that finality is the "essential feature" of arbitration). But see BRUNET ET AL., supra note 75, at 18 ("The case for efficiency as a paramount value underlying arbitration is tepid at best.").

205. See generally Cole, supra note 163, at 764-67, 770 (discussing the reasons arbitration is attractive to employers); Stephen J. Ware, The Case for Enforcing Adhesive Arbitration Agreements-with Particular Consideration of Class Actions and Arbitration Fees, 5 J. AM. ARB. 251, 254-64 (2006) (arguing that adhesive agreements benefit society by, among other things, reducing costs). 
could also have negative effects for those forced into arbitration. Namely, if they win, and if the appeal-for-legal-error rule applies to all parties, then the commercial parties could freely appeal, thereby increasing the expense of litigating the claim. ${ }^{206}$ Finally, arbitrators usually do not issue reasoned opinions, and the lack of reasoned opinions makes it more difficult for reviewing courts to determine whether the arbitrator made a legal error. ${ }^{207}$ Thus, the lack of reasoned opinions would inhibit the effectiveness of my proposal. ${ }^{208}$

These are all valid, debatable points. But none is compelling enough to avoid recognizing that courts should review awards in mandatory arbitration under a different standard or that parties subjected to mandatory arbitration deserve greater procedural rights. ${ }^{209}$ Specifically, the ex ante freedom of contract argument carries little weight because parties who are asked to sign arbitration agreements often fail to read them and, even if they did, they would have little power to negotiate terms. $^{210}$ In other words, they usually have not given informed consent and therefore have not freely contracted to arbitrate. ${ }^{211}$ Also, the notion of finality in arbitration is overblown. Finality should be a concern only if the parties intended the arbitration to be final-an idea premised on party autonomy. When one of the parties does not give informed consent to arbitrate, that party cannot have intended arbitration as the final forum for resolving a dispute. ${ }^{212}$ Additionally, whether businesses will avoid including mandatory-arbitration clauses in their agreements gives me little concern. Businesses will base their decisions on a cost-benefit analysis. If mandatory arbitration's benefits still outweigh its costs, which they probably will, then businesses will continue using it. If not,

206. Kirgis, supra note 202, at 54.

207. Hayford, supra note 10, at 125-26; Hans Smit, Mandatory Law in Arbitration, 18 AM. REv. INT'L ARB. 155, 168 (2007) (noting that a preference for nonreasoned awards "renders judicial review more difficult").

208. But it would not eliminate the effectiveness of my proposal. See Halligan v. Piper Jaffray, Inc., 148 F.3d 197, 202-04 (2d Cir. 1998) (overturning an award under the manifest-disregard standard without the benefit of a reasoned award); Montes v. Shearson Lehman Bros., 128 F.3d 1456, 1459-62 (11th Cir. 1997) (same).

209. See Cole, supra note 163, at 789 (calling for amendments to the FAA "to protect one-shot players from potential abuses by repeat players"); Kirgis, supra note 202, at 5-6 ("At the end of the day, every policy argument in favor of arbitration without judicial review can be met by a contrary argument in favor of curtailing arbitration.").

210. See supra note 175 and accompanying text.

211. BRUNET ET AL., supra note 75, at 7 ("A consumer who is forced to arbitrate a dispute without having knowledgeably consented to arbitration loses both the freedom to use the court system and the freedom to contract in a knowing fashion.").

212. Id. at 23-24. 
they won't. ${ }^{213}$ Either way, my proposal avoids the harsher sanction of eliminating mandatory arbitration altogether, which would take the decision of whether to arbitrate completely out of businesses' hands.

Nevertheless, in deference to some of the concerns with my basic proposal, consider the following additional tweaks. First, courts should sanction parties for frivolous appeals that rely on the manifest-disregard standard. Ideally, the possibility of sanctions would appear in section 10 of the FAA after manifest disregard is codified, if Congress codifies the doctrine. ${ }^{214}$ This would give courts additional textual justification for sanctioning parties who file frivolous appeals. ${ }^{215}$ Alternatively, courts could use their inherent powers over the litigation process to sanction parties who improperly rely on manifest disregard. ${ }^{216}$ The Eleventh

213. One potential critique here is that I seem to believe that businesses can perform cost-benefit analyses but consumers, employees, or franchisees cannot. My response to this is twofold. First, businesses have better information. They are repeat players, they know what the arbitration agreement says, they know the effects of the arbitration agreement, and they know the costs of arbitration. Consumers, employees, and franchisees usually have none of these advantages. Also, consumers, employees, and franchisees often do not have the luxury of performing a cost-benefit analysis. If they need a certain product and all sellers of that product require arbitration, if they need a certain job and all employers offering that job require arbitration, or if they want to purchase a certain franchise and the franchisor requires arbitration, then they have no choice in whether they will arbitrate any disputes related to that product, job, or franchise. See supra notes 165-68 and accompanying text. Second, the procedural justice studies show that parties want fair results (this is true for studies performed before and after disputes arise). See, e.g., Naimark \& Keer, supra note 69 , at 204. The problem is that before disputes arise, parties discount the possibility of a dispute ever arising. Then after disputes arise, parties realize how limited their rights are under the arbitration agreement. In other words, cost-benefit analyses performed before disputes arise may tend to assign too little weight to the possibility of a dispute arising.

214. See Drahozal, supra note 150 , at 235.

215. Other textual bases exist for sanctioning parties for frivolous appeals. See, e.g., FED. R. APP. P. 38 ("If a court of appeals determines that an appeal is frivolous, it may, after a separately filed motion or notice from the court and reasonable opportunity to respond, award just damages and single or double costs to the appellee."). However, explicitly including sanctions as a possibility for frivolous appeals under the manifest-disregard standard should have an additional deterrent effect.

216. See B.L. Harbert Int'1, LLC v. Hercules Steel Co., 441 F.3d 905, 913-14 (11th Cir. 2006) ("A realistic threat of sanctions may discourage baseless litigation over arbitration awards and help fulfill the purposes of the pro-arbitration policy contained in the FAA."), abrogated by Frazer v. CitiFinancial Corp., 604 F.3d 1313 (11th Cir. 2010); see also Int'1 Ass'n of Machinists \& Aerospace Workers v. Texas Steel Co., 538 F.2d 1116, 1121 (5th Cir. 1976) (stating that courts have authority to award costs for frivolous appeals from arbitration awards). 
Circuit recently did so. ${ }^{217}$ And it did so based in part on the frequency of parties seeking vacatur under this standard. ${ }^{218}$

While sanctions' effectiveness in deterring frivolous appeals may be debatable ${ }^{219}$ taking this step is appropriate in this context, particularly if the sanctions are levied based on an objective standard. That is, courts should consider whether the appeal itself has any merit, not whether the attorneys filing it did so in bad faith. ${ }^{220}$ Subjective intent should be irrelevant. Although this may deter some parties from filing valid appeals under the manifest-disregard standard, ${ }^{221}$ it should also force attorneys to "stop, think, and investigate" before filing an appeal, particularly if no showing of bad faith is required before sanctions are imposed. ${ }^{222}$ This, presumably, would reduce the number of meritless pro forma appeals under manifest disregard. ${ }^{223}$

For the second tweak, a court should allow only the party forced into arbitration to appeal for legal error under the broader manifest-disregard standard. The obvious objection to such a rule is that businesses would find it unfair - they would object to being bound by a legally inaccurate

217. B.L. Harbert Int'l, $441 \mathrm{~F} .3 \mathrm{~d}$ at 914 ("The warning this opinion provides is that in order to further the purposes of the FAA and to protect arbitration as a remedy we are ready, willing, and able to consider imposing sanctions in appropriate cases."). Remember, however, that the B.L. Harbert court made this announcement based on the current manifest-disregard standard. It would be easier for courts to issue sanctions under the current standard, which requires some proof that the arbitrator consciously disregarded known, applicable law than it would under my proposed standard, which requires only legal error.

218. Id. ("The notice it provides, hopefully to even the least astute reader, is that this Court is exasperated by those who attempt to salvage arbitration losses through litigation that has no sound basis in the law applicable to arbitration awards."). Parties rely on manifest disregard in attempting to overturn arbitration awards more than any other ground for vacatur. See, e.g., LeRoy \& Feuille, supra note 10, at 189; Scodro, supra note 94, at 566-67.

219. See Mark R. Kravitz, Unpleasant Duties: Imposing Sanctions for Frivolous Appeals, 4 J. APP. PRAC. \& PROCESS 335, 343-47 (2002) (noting that some courts are reluctant to impose sanctions for frivolous appeals even though they have the statutory authority to do so, which, of course, would have a negative effect on deterrence); see also Roger J. Miner, Lecture, Professional Responsibility in Appellate Practice: A View from the Bench, 19 PACE L. REV. 323, 341 (1999) ("“I]t is a rare case in which we sanction even those who take frivolous appeals.").

220. See generally Scott A. Martin, Note, Keeping Courts Afloat in a Rising Sea of Litigation: An Objective Approach to Imposing Rule 38 Sanctions for Frivolous Appeals, 100 Mich. L. ReV. 1156 (2002) (noting courts' disagreement over whether bad faith should be a consideration in levying sanctions and suggesting an objective standard for courts to use).

221. See Talamini v. Allstate Ins. Co., 470 U.S. 1067, 1071 (1985) ("Creating a risk that the invocation of the judicial process may give rise to punitive sanctions simply because the litigant's claim is unmeritorious could only deter the legitimate exercise of the right to seek a peaceful redress of grievances through judicial means.").

222. Martin, supra note 220, at 1180 (quoting Berwick Grain Co. v. Ill. Dep't of Agric., 217 F.3d 502, 505 (7th Cir. 2000)). Although the Berwick Grain case involved sanctions under Federal Rule of Civil Procedure 11, the same principle should apply to sanctions for frivolous appeals.

223. See id. at 1179-81. 
award when the other party is not. But businesses can still rely on the narrow manifest-disregard standard. ${ }^{224}$ And they can still manipulate the procedural fairness of arbitration by drafting the arbitration agreement. For example, they may still contract around any default rules that might otherwise favor consumers, employees, and the others who are forced to arbitrate. $^{225}$ Thus, they would simply have to weigh the limitation on their right to appeal under the broader standard against their ability to otherwise shape arbitration procedures and then make an economic decision on whether to continue requiring mandatory arbitration.

The third tweak to this basic proposal is that I would require reasoned opinions in mandatory arbitration. ${ }^{226}$ While requiring reasoned opinions would increase the formality and expense of the arbitration, which is the main objection to such a rule, ${ }^{227}$ it would simplify the task of reviewing the awards for legal error. Both the parties involved and the appellate court would have a better understanding of how the arbitrator decided the case. ${ }^{228}$ Also, this would increase the likelihood that arbitrators would at least try to follow the law, thus increasing the accuracy of awards while reducing the likelihood of judicial review. ${ }^{229}$ So, for mandatory arbitration at least, the benefits of reasoned opinions

224. Although, courts should apply sanctions for frivolous appeals under this standard, too.

225. But any attempt to contract around default rules would be reviewed under the unconscionability standard. Doctor's Assocs. v. Casarotto, 517 U.S. 681, 686-87 (1996).

226. Labor arbitrators usually already provide written opinions, so the rule I propose should not affect arbitrations between employers and employees. See Stephen L. Hayford, A New Paradigm for Commercial Arbitration: Rethinking the Relationship Between Reasoned Awards and the Judicial Standards for Vacatur, 66 GEO. WASH. L. REV. 443, 444 n.3 (1998) ("Labor arbitrators write reasoned awards because the parties to the labor arbitration process expect them to do so. Over the fifty-odd years of labor arbitration in the United States, those substantive written awards have become an integral part and a primary dimension of the process.").

227. Id. at 446-47.

228. Id. at 447 ("Ironically, an award made without explanation of the arbitral analysis upon which it is based may well encourage attempts to vacate, because the loser in arbitration has "no principled basis for accepting, however reluctantly, the wisdom of the award."' (quoting Stephen Hayford \& Ralph Peeples, Commercial Arbitration in Evolution: An Assessment and Call for Dialogue, 10 OHIO St. J. ON DisP. Resol. 343, 402 (1995))).

229. Arbitrators would not want a high reversal rate because it would decrease their marketability. Parties to arbitration would avoid selecting them as arbitrators out of fear that they would make an error in the award, thereby increasing the likelihood of an appeal. Also, although arbitration has measures in place to protect against bias, my proposal increases those protections. Because arbitrators would want a low reversal rate under my proposal, they would be less inclined to rule in one party's favor because of bias. See Thomas Burch, Necessity Never Made a Good Bargain: When Consumer Arbitration Agreements Prohibit Class Relief, 31 FlA. ST. U. L. REV. 1005, 1032-33 (2004) (noting the incentives that arbitrators and arbitration institutions already have to remain unbiased). 
outweigh their costs and would improve the procedural fairness of mandatory arbitration for the parties subjected to it. ${ }^{230}$

Overall, this proposal makes mandatory arbitration more palatable from a procedural-justice standpoint because it enhances accuracy and provides greater decision control. ${ }^{231}$ It also makes mandatory arbitration's procedures seem more fair, and it provides an alternative to the elimination of mandatory arbitration altogether. Moreover, it attempts to fix some of the problems with manifest disregard as it is currently defined. While these fixes may not be perfect, they are an improvement over the current manifest-disregard standard, which, when applied narrowly, negatively impacts mandatory arbitration's procedural justice.

\section{CONCLUSION}

The Supreme Court has made little effort to define manifest disregard in the fifty years since it created the doctrine, so lower courts have been free to apply the doctrine as they see fit. While most have applied it narrowly in the name of efficiency, some have applied it broadly by reviewing awards for legal error. Consequently, manifest disregard has become central in the debate over whether efficiency or accuracy is the more important arbitration policy.

The relative emphasis placed on efficiency and accuracy should depend on the type of arbitration. Pure commercial arbitrations are intended to be an efficient process, and the parties to those arbitrations care less about the accuracy of their awards. So it makes sense that we should limit judicial review in that context. But for mandatory arbitration, noncommercial parties have little choice in deciding whether to accept the arbitration clause-if they even know it is in their agreement - and the agreement itself is drafted to favor the commercial party. ${ }^{232}$ It thus makes sense to give the parties subjected to mandatory arbitration greater procedural protections.

230. My proposal could work without the reasoned opinion requirement. Courts could still review the record and attempt to determine whether the arbitrator made a mistake. However, requiring courts to discern legal error from the record would be less efficient and less likely to result in vacated awards.

231. While commercial parties who mandate arbitration in their agreements may disagree, at the very least my proposal offers an alternative to the elimination of mandatory arbitration altogether, an idea that is gaining popular appeal. See sources cited supra note 5.

232. BRUNET ET AL., supra note 75 , at 7. 
The proposal here does that. Specifically, it increases decision control for the parties who are subjected to mandatory arbitration by allowing those parties to appeal arbitrators' awards for legal error. But to avoid overwhelming courts with appeals, it also allows courts to sanction parties for frivolous appeals based on an objective standard that requires no bad faith before sanctions are levied. It also incentivizes arbitrators to avoid legal error because increased errors will result in decreased demand for those arbitrators' services. Overall, this proposal provides an alternative to the incoherent and inequitable manifestdisregard standard that we currently have, and, more broadly, it offers an alternative to eliminating mandatory arbitration altogether - an idea that seems to be gaining popular appeal. Thus, I submit it for consideration as a new approach to the manifest-disregard standard going forward. 